\title{
Straight Ahead on Red: How Foreign Direct Investment Empowers Subnational Leaders
}

\author{
Edmund J. Malesky University of California-San Diego
}

This paper tests the hypothesis that increasing stocks of foreign direct investment (FDI) can lead to de facto decentralization in the form of autonomous reform experiments by subnational leaders. Because these reform experiments may attract FDI in subsequent years, there is a possibility of endogeneity. As a result, the methodology is a simultaneous equation model of 61 Vietnamese provinces between 1990 and 2000. Stocks of FDI as a percentage of GDP are regressed on a measure of autonomy derived from a content analysis of Vietnamese stateowned newspapers. Every time a province is cited in the papers for violating central laws on economic policy by engaging in reform experimentation, it is coded as a case of autonomy. The central question of the analysis is: how much FDI is needed for a province to believe it has the bargaining power to challenge central authority for the first time in a given year? Using this approach, I find strong evidence for the influence of FDI on local autonomous economic reform experiments.

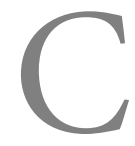

hen Yun, a conservative Chinese economic policy maker, once famously opined that the leaders of the coastal province of Guangdong were adhering to a "traffic light philosophy." Leaders responded to the center's policies in one of three ways. "When the red light is on, they make a detour and proceed as they were going; when the yellow light is on, they ignore it and keep going at the same speed; and when the green light is on, they rush ahead at full throttle," (Lam 1999; Pye 1991). It wasn't just Guangdong; at repeated internal meetings in 1995, Jiang Zemin complained that eight provinces were virtually "running their own show" in regard to economic policy (Lam 1999).

The traffic light offers a vivid depiction of a concept scholars studying local-central relations have termed de facto decentralization, the notion that even in a unified state, subnational leaders can wrestle away policymaking autonomy, especially in regard to economic decisions, from the central government (Herrera 2005; Jones-Luong 2003; Mitchneck 1995). Chen Yun, after all, was an economic conservative who was not supportive of Guangdong's efforts. According to some scholars, eventually de facto decentralization will be codified into formal rules and institutions, nominally granting to subnational leaders the policy autonomy they had long ago seized (Gallagher 2002; JonesLuong 2003; Zweig 2002). But where did the traffic light come from? That is, why did some provinces and not others have the authority to both experiment within the confines of existing Chinese law and even break central law when its red lights were deemed to impede their progress? Answering this question correctly has important implications for our understanding of the motivations behind formal decentralization and federalism in the comparative politics literature, as a number of scholars have shown that the formal rules governing decentralization are a function of the preexisting bargaining power and policy authority held by subnational entities (Bolton and Roland 1997; Hutchcroft 2001; Solnick 1998 Ziblatt 2004).

One possible answer studied across a range of countries with different economic structures is that a critical source of de facto decentralization is integration with the world economy, specifically access to foreign direct investment (FDI), as it provides subnational actors with resource flows that can support increased independence from central government authority, while simultaneously increasing the importance of subnational policy for economic development (Echeverri-Gent 2000; Gallagher 2002).

Studying Kazakhstan, Jones-Luong (2003) found that the proliferation of FDI empowered local leaders $v i s-\grave{a}$-vis the center; while during the Soviet period, the central government could use its monopoly to 
control scarce resources and expenditure distribution, once foreign investment projects were approved locally in Kazakhstan, the regions became financially independent and powerful. China specialists have argued that the dual forces of economic opening and decentralization fostered growth of provincial bargaining power and autonomy vis-à-vis a center with "waning" state capacity (Jia Hao and Lin Zhimin 1994; Shirk 1993, 1994; Wang 1995). In Mexico, Diaz-Cayero, Magaloni, and Weingast (2003) found that the most internationally integrated regions were most likely to defect to the opposition from the Institutional Revolutionary Party (PRI), as they were less reliant on PRI controlled transfers. Orttung (2004) has even claimed that the importance of FDI-induced subnational autonomy is one reason that foreign investors prefer to protect their legal rights by developing particularized relations with Russian governors, rather than press for universalized rules at the national level.

Evaluating the claims of these authors is difficult, because while all engage in impressive historical and archival research, none have subjected their theories to a rigorous empirical test due to measurement difficulties. No standard index of de facto decentralization exists across all subnational units within a country that can adequately capture this process. Secondly, empirical tests are also burdened by problems of endogeneity, as local autonomy over economic policy may be a source of attraction for foreign investors attempting to choose subnational investment locations (Meyer and Pind 1999; Meyer and Nguyen 2005; Taube and Ogutucu 2002).

Finding a way to resolve these two empirical problems and isolate the impact of FDI on de facto decentralization also has important implications for the literature on the political economy of FDI, which has predominantly addressed national-level political determinants of FDI, rather than looking at the role of FDI in helping shape these institutions, especially at the subnational level (Blanton and Blanton 2007; Henisz 2000; Henisz and Delios 2004; Jensen 2003, 2006; Li and Resnick 2002).

In this paper, I exploit an interesting element of the Vietnamese polity to measure provincial autonomy and provide a rigorous test of theories linking FDI and de facto decentralization, which I define as autonomy over economic policy assumed by local authorities (not granted to them) outside of central legislation. Because the Vietnamese Government uses its stateowned press as a forum to denounce provinces which push beyond central tenets, a content analysis of a variety of these newspapers offers an ideal measure to capture the amount of autonomous incidents that each province has accumulated over the course of the 1990s. I track six daily newspapers from 1990 to 2000 and record every time one of Vietnam's 61 provinces ${ }^{1}$ was cited for willfully pushing beyond central economic or administrative policy (red lights) and every time provinces took advantage of ambiguity in central law to enact their own reforms (yellow lights). In Vietnam, such explicit usurpations of economic policy authority by provincial officials are popularly referred to as fence breaking (pha bo rao or xe rao), a term introduced to academics in Fforde and de Vylder (1996). The central question of the analysis is: how much FDI is needed for a province to believe it has the bargaining power to challenge central authority for the first time in a given year? To deal with the problem of endogeneity, I test my theory with a simultaneous equation model.

The paper is divided into two main sections. First, I detail the micrologic of the impact of FDI on provincial autonomy in Vietnam, discussing the preferences of both provincial and central actors. In this section, I do not assume that central leaders are naïve or myopic; instead I show that central leaders were hamstrung to prevent fence breaking due to institutional constraints and their need for the budget revenue produced by local actors. With some abstraction, similar micrologics can be derived for other developing states. Second, I outline and test the simultaneous equation model of FDI on cases of provincial autonomy. Using this approach, I find strong evidence for the impact of FDI on the probability of autonomous actions at the provincial level.

\section{The Micrologic of FDI and Provincial Autonomy in the Case of Vietnam}

A cross-national test of my theory is presently undesirable due to the lack of comparable measures of de facto decentralization across transition states. Excellent pooled time-series work has certainly been done on the effect of economic integration on formal decentralization cross-nationally (Alesina, Spolaore, and Wacziarg 2000; Bolton and Roland 1997; Gourevitch 1979; Hiscox 2000), but this work is testing a fundamentally different theory: that subnational governments

\footnotetext{
${ }^{1}$ Actually, the number of Vietnamese provinces has increased from a starting point of 40 at the beginning of the time period to 44 in 1991, 53 in 1992, 61 in 1997, and 64 in 2004. I use sets of unbalanced panel over the time series to account for provincial separations. When a province is split, its panel ends in the data set and the two new provinces begin anew in the subsequent year.
} 
benefiting from economic integration would demand decentralization or even secession as a way of avoiding the redistribution of their winnings to poorer regions. Advocates of de facto decentralization, however, claim that better integrated subnational governments may not negotiate for formal decentralization, but instead simply take it without legislative changes. What variable do we use if we want to understand this informal authority? Helmke and Levitsky (2005) call for political scientists to take seriously the role of informal institutions, requiring that an analyst know a case intimately enough to be able to understand the informal mechanisms at play in a country and deduce logical predictions from those mechanisms. This cannot be done with any degree of accuracy in a crossnational test. Furthermore, most variance in such test would be cross-national rather than longitudinal, granting analysts little insight into how FDI can impact policies in any one country over time. Scholars must seek ways to expand the number of observations within a setting where the informal institutions share similar traits and can be properly compared (King, Keohane, and Verba, 1994; Snyder 2001). Only then can we understand the political mechanisms that are unleashed by the entry of international economic actors.

I resolve this problem by testing the results within the single country of Vietnam, where a metric exists to compare autonomy across all of Vietnam's 61 provinces. In doing so, I keep in mind Gallagher's (2002) finding from China that the observable implication of the above argument is that not only should we find a high correlation between concentrated FDI and subnational autonomy within transition states, but that such autonomy should manifest itself in a series of local reforms beneficial to foreign investors. To find evidence that more FDI leads to more investor friendly policies would not be surprising; indeed, some might see this conclusion as almost self-evident. What would in fact be surprising would be to find evidence that FDI actually spurs provincial economic reform policies-even when central law does not provide for such activity and dominant actors at the central level have incentives to oppose the activity. This, of course, is the definition of de facto decentralization discussed by Jones-Luong (2003). Vietnam is a particularly appropriate test because of the large number of provinces and high variance of both FDI and autonomy across Vietnamese provinces, despite relatively even starting points. As a result, it offers an ideal quasi-experimental setting. Provinces differed in initial structural conditions, such as geography and proximity to markets, but all faced the central decision to open up to the global economy in 1986 with the exact same political institutions.

\section{FDI in Vietnam}

Some evidence seems to suggest that Vietnam should be an extremely difficult case for my theory of FDI's influence at the provincial level. The country has an explicit fear of the negative impacts of a foreign economic presence in their society, generated by over two millennia of negative experience with foreign imperialism. A number of Vietnamese leaders have warned of the need to prevent the pernicious influence of capitalist countries on Vietnamese domestic politics, an action the Vietnamese ironically refer to with the benign sounding "peaceful evolution," (Bolton 1999; Ky 1996; Schwarz 1996). Proud of their independence after a number of long and painful wars, many heroes-turnedpoliticians were unlikely to allow their politics to be dictated by outsiders.

Nevertheless, in the four years after the 1987 Foreign Investment Law, \$168 million dollars flowed into Vietnam, mostly into off shore oil and gas projects. After 1991, FDI formed with joint ventures in hotel and tourism projects, as well as export-oriented products such as garments, food processing, and automobiles that were thought to be easily managed (Mai 1998). FDI became increasingly important in Vietnam's economy. By 2000, implemented FDI amounted to $\$ 25$ billion (Masina 2004) and although foreign-invested companies employed less than $1 \%$ of the total workforce in Vietnam, they cumulatively accounted for around $27 \%$ of the country's (nonoil) exports, $35 \%$ of industrial output, and 13\% of Vietnam's GDP (FDI stock was equal to $50 \%$ of GDP; Freeman and Nestor 2004).

There was a high regional concentration of FDI in Vietnam from the very onset of the reform era, as can be seen in Figure 1 (Panel A). 60\% of approved projects between 1990 and 1994 were in HCMC and three neighboring provinces. Hanoi also was an early winner in the FDI attraction race, but its important status proved an exception to the primary interest in the South. ${ }^{2}$ From a political perspective, the southern concentration was surprising. Although the original FDI law was amended in both 1990 and 1992, until the 1996 revision, final approval on FDI decisions had to be made in Hanoi and a province's primary hope of attracting investment rested in a warm and informative greeting for investors, who could then lobby officials at

\footnotetext{
${ }^{2}$ At this time, FDI came primarily in the form of joint ventures with state owned enterprises, accounting for over $70 \%$ of approved projects and $75 \%$ of total registered capital between 1988 and 1994. By 2000, 100\% foreign owned enterprises would account for $56 \%$ of total projects and $40 \%$ of registered capital, demonstrating the decreasing role of SOEs.
} 
Figure 1. Maps of Vietnam

Panel A:

Regional Distribution of Stock of Foreign Direct Investment Per Capita in 2000

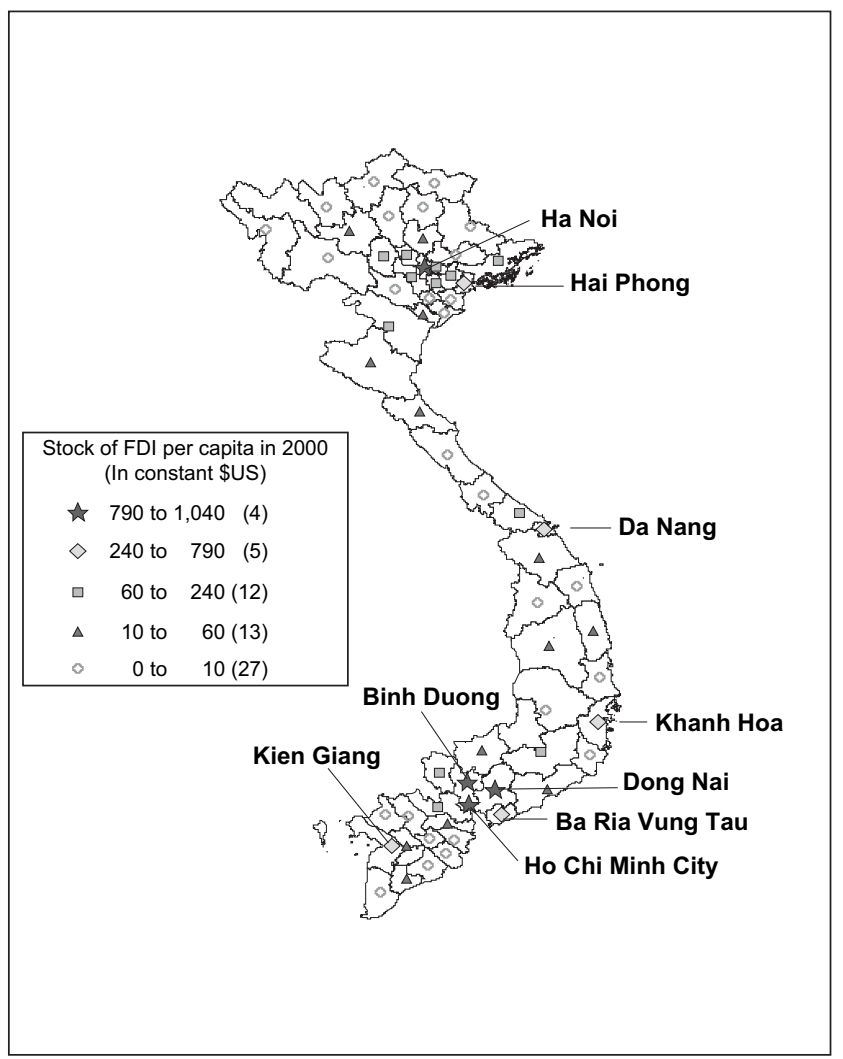

State Committee of Cooperation and Investment (SCCI) about where they wanted to set-up shop. Provincial People's Committees were only allowed to send letters to the SCCI, preparing documents for investors, and providing their evaluation of a particular investment project. Southern provinces excelled at this early system.

Reliance on FDI tapered off in 1997 with the onset of the Asian Financial Crisis, where Vietnam was impacted indirectly by the loss of investment from its East Asian neighbors (Fforde 2002; Kokko, Kotoglu, and Krohwinkel-Karlsson 2003). Nevertheless, the stock of FDI as a percentage of GDP was fifth among all transition states at the end of the decade (UNCTAD 2001), and Vietnam was the number one recipient of FDI among all developing and countries in transition in proportion to size of its economy (FIAS 1999).

It is important to remember that most of the investors over the course of the '90s were firms from neighboring Asian countries, who were primarily
Panel B:

Regional Distribution of Autonomous Actions

(Fence-breaking)

(1990-2000)

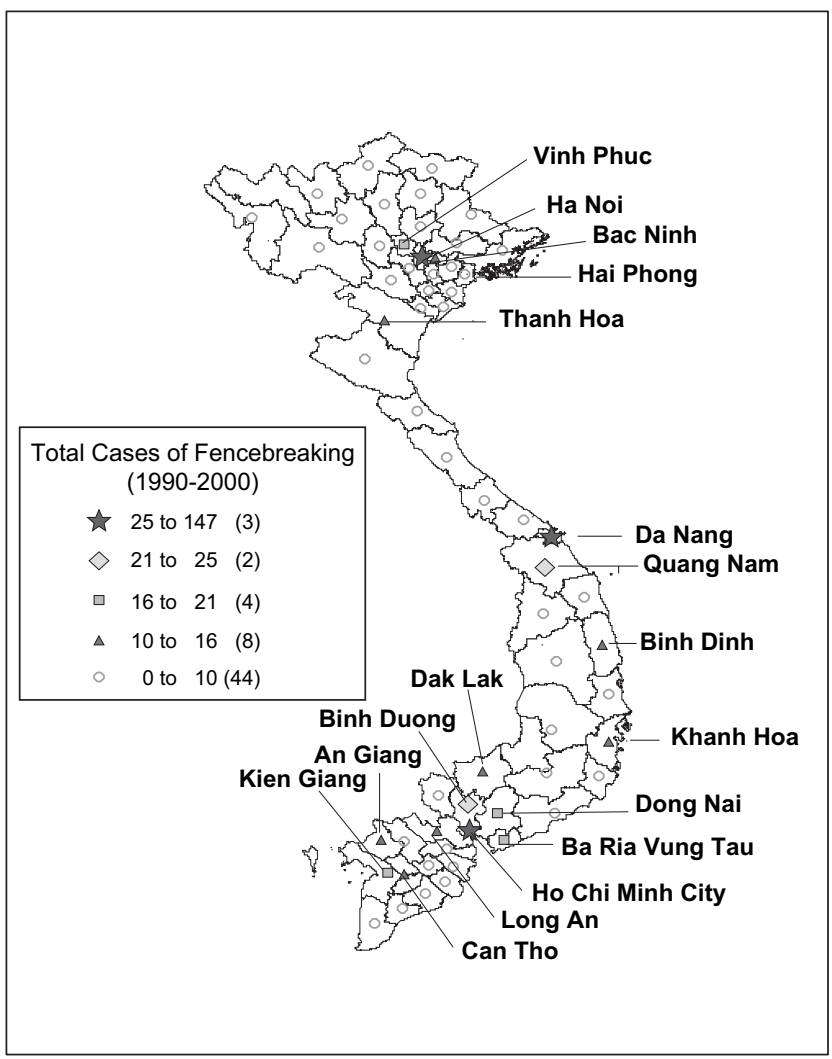

interested in using Vietnam as an export platform (Anh 2004; Mai 1998). By 2001, the top five investors in the country by nationality were Singapore, Taiwan, Hong Kong, South Korea, and Japan, with Malaysia and Thailand in the top 10 (GSO 2002). These countries accounted for $64 \%$ of total capital and $59.7 \%$ of licensed projects. Primarily due to their influence, foreign investors' share of exports rapidly grew from $27 \%$ in 1995 to $45 \%$ by 2001 . Most of the Asian investors in Vietnam already had significant operations elsewhere in Asia. They were familiar with investing in the Asian context and conscious of how to manage those investments most effectively. As a result, Asian investment projects were less likely to fail than their European and American counterparts (Kokko, Kotoglu, and Krohwinkel-Karlsson 2003). Most importantly, Asian investors were not nearly as daunted by opaque legal institutions and property rights as their American and European counterparts for two reasons. First, their primary motivations had more to do with structural 
and commercial obstacles to investment than governance (JBIC 2005). Second, when government institutions did pose problems, Asian investors were more likely to resort to relationships in order to push for changes that would ameliorate the difficulties. Most importantly for this paper, Asian investors were far more inclined to use relationships with provincial governments to achieve their policy goals (Mason 1998).

\section{Preferences of Provincial Actors}

To understand how the cumulative stock of FDI influenced provincial-central relations and eventually inspired de facto decentralization, it is important to carefully spell out the incentives of actors in the Vietnamese polity.

Provincial officials in Vietnam (specifically Provincial People's Committee Chairman and Party Secretaries) have three sets of incentives: prestige and power, pecuniary benefits for themselves and related family businesses, and community interests in providing employment and better living conditions for citizens in their provinces. Increasing provincial revenue in whatever way possible is the primary means by which provincial People's Committee officials achieve these goals. Nguyen Dinh Cung of the Central Institute for Economic Management put it this way in a 2001 interview with the author: "Provincial revenue is the most important indicator of success and power of all provinces. It is their primary target."

The importance of revenue results from a peculiarity of the financial system; Hanoi sets national taxes through the Ministry of Finance but returns to provinces all revenue they generate above a biannually negotiated target (World Bank 1996). As Fritzen put it,

"The fiscal system is set up to reward with greater administrative discretion and resources to those provinces which garner greater levels of FDI and tax revenue... Since both are highly concentrated on a few provinces, the situation of provinces with respect to de facto administrative discretion can be quite divergent." $(2002,11)$

Actually, it was more than just a few provinces with enhanced authority. While only eight provinces ran budget surpluses throughout the 1990s, ${ }^{3}$ about 41 out of 64 met their targets on a regular basis (Bird, Litvak, and Rao 1995; GVDWG 2000; Rao, Bird, and Litvack 2001; Vasavakul 2002). This above-target revenue could be pumped back into infrastructure and social welfare spending, which satisfied all three

\footnotetext{
${ }^{3}$ Sixteen provinces averaged budget surpluses between 1997 and 2000, when aggregate provincial-level budget data was made available to the public.
}

preferences of provincial officials. As Echeverri-Gent wrote of the Chinese tax system prior to 1994, "revenue contracting provided the provinces with economic incentives for growth and autonomy to creatively pursue it" $(2000,5) .{ }^{4}$ In short, provinces that were not major contributors to central coffers still possessed a fiscal incentive to fence break.

Between 1990 and 2000, FDI contributed to provincial revenue directly through a range of different taxes. These included: a licensing fee equal to $0.01 \%$ of the project amount, a $25 \%$ tax on net income (with special rates available for projects in fields encouraged by the Vietnamese government), a value added tax (VAT) with an average rate of $10 \%$, a tax on income remitted from abroad, a special sales tax on luxury goods, and a personal income tax on high earners of $50 \%$ for foreigners and $60 \%$ for Vietnamese employees, plus a $30 \%$ surcharge on benefits (Asia Times 2000). Some provinces granted tax holidays to encourage investment, especially in industrial zones, but these holidays were relatively short-lived, averaging about two years (Asia Times 2000; Yui 2004). FDI also provided substantial opportunities for indirect revenue. After foreigners were allowed to hold land use rights certificates in 1996, fees on land transfers and land use rights assignments added to provincial coffers. Other sources of indirect revenue included customs fees, import taxes on various types of equipment, and energy usage fees. All tended to be higher in FDI-recipient provinces (MOF 2006).

The Ministry of Finance did not release disaggregated data on provincial budgets until 2000, so it is impossible to know the exact contribution of these individual taxes to FDI for all provinces before that time. ${ }^{5} 2000$ data, however, show that income taxes and VAT from foreign companies accounted for about $5.2 \%$ of national revenue (about $\$ 316$ million). If we include the income tax from high earners, licensing fees, and taxes on imported equipment-where only a marginal amount was contributed by local firms, total FDI contribution to national revenue was about $14.2 \%$ (GSO 2001). By contrast, the FDI contribution to revenue in the high-FDI provinces of Binh Duong and Vinh Phuc was 22\% (\$18 million) and 25\%

\footnotetext{
${ }^{4}$ For the highest revenue earners, the Central Government negotiates percentage return rates. Ho Chi Minh City (HCMC), for example, can keep 29\% (15\% before 2001) of its revenue, while Binh Duong can keep 44\%. Given the amount of revenue collected in these provinces, however, the return can be substantial-HCMC and Binh Duong, two of the largest FDI recipients, were able to retain about $\$ 870$ million and $\$ 20$ million, respectively, in 2000 .

${ }^{5}$ Statistical handbooks from individual provinces occasionally provide data from as early as 1996.
} 
(\$11 million), respectively (Binh Duong Statistical Office 2001; Vinh Phuc Statistical Office 2001). At the low end of the spectrum were provinces such as $\mathrm{Ha}$ Tinh, where FDI accounted for $0.009 \%$ of provincial revenue (\$8000; Ha Tinh Statistical Office 2001).

Export-oriented FDI also contributed to Vietnam's budget through export duties. Unfortunately, export duties are listed as a single line with import duties and luxury taxes in provincial budgets, leading to serious difficulty in disentangling the true contribution of exports. Moreover, the ownership type of the exporter is not listed, so it is impossible to distinguish export duties paid by foreigners from those paid by domestic firms. With these limitations in mind, we can say that this particular line item accounts for 14.8\% of national revenue, but almost $50 \%$ of revenue in Vinh Phuc and 24\% in Binh Duong (Binh Duong Statistical Office 2001; Vinh Phuc Statistical Office 2001). In Ha Tinh, with very little FDI but a large stateowned mining sector, the same line item accounts for $35 \%$ of revenue (Ha Tinh Statistical Office 2001).

The difference between these provinces is that while Binh Duong and Vinh Phuc averaged budget surpluses over the 1990s, Ha Tinh actually had a net deficit equal to $12 \%$ of provincial GDP, which was made up for by central transfers. This finding is helpful for sorting out the difference between FDI and exports on provincial budgets among provinces. Exports alone were not the route to fiscal surpluses because state sector exports were often counterveiled by off-setting expenditures to maintain provincial SOEs. Exports/ GDP has a bivariate correlation of 0.10 with net surplus (provincial revenue minus provincial expenditures) and is not significantly different from 0 . By contrast, implemented FDI/GDP has a .56 correlation with net surplus and is significant at the 0.01 level. ${ }^{6}$ Indeed, of the 16 provinces running budget surpluses between 1997 and 2000, 13 of the provinces had implemented FDI that was greater than $40 \%$ of GDP over the period. Thus, the road to surplus revenue above fiscal targets was through healthy amounts of foreign investment, but could be enhanced by export-oriented FDI due to the additional customs duties.

The political implication of beating revenue targets was two-fold. First, provincial officials had an important incentive to accede to the policy demands of foreign investors if they were the dominant source of revenue in the province. If the central government was not willing to grant permission for their policy requests, provincial officials were likely to fence break

${ }^{6}$ See bivariate correlations in online Appendix 2 at http://journalofpolitics.org/articles.html. in order to retain the revenue flows. Second, provinces with revenue above the targets were also much less dependent on the central government for resources and therefore harder to reign-in by reducing transfers.

In China, the decentralizing impact of fiscal targeting could be countervailed by incentives produced by the centrally controlled promotion of cadres (Sheng 2007; Whiting 2001); in Vietnam this appears to be less true. Due to historical and cultural differences, very few southern provincial leaders were promoted (or opted to accept promotions) to the central government until the 2006 Party Congress. By convention, a Southerner traditionally takes the position of Prime Minister, but on the whole, southern provinces (which are responsible for the preponderance of FDI and fence breaking) are underrepresented in the central government. Over the past three administrations, only $12 \%$ of cabinet ministers came from the South, as opposed to $49 \%$ from the North and 39\% from the Central provinces (NGTCHCVN 19982004). These numbers seem to indicate that the possibility of central promotion offers little incentive for southern leaders to curtail fence breaking.

It is also worth noting that there is a common misunderstanding among recent observers of Vietnam that this targeting system was transplanted to Vietnam in the mid-90s with the Budget Law of 1996. Detailed lists of provincial revenue targets have been made available from the Ministry of Finance dating back to 1992. The Budget Law was in fact an attempt by the central government to codify a method of intergovernmental transfers that had been taking place since the 1980s without a concrete legal framework (Abrami 2003; Naughton 1995; Tu 1987). The most important contribution of the 1996 Budget Law was not the fiscal targeting, but the fact that provincial governments now had a greater incentive to look toward other forms of enterprises rather than the state sector to beat their revenue targets. As FDI began to replace SOEs as the dominant revenue earners in some provinces, foreign investors gained a stronger voice in local policy.

In FDI-recipient provinces, foreign investors became the new winners in an altered policy space, allowing them to unlock the partial reform equilibrium created by early reforms (Hellman 1998). The early winners of economic reform in Vietnam were central and provincial SOEs, which benefited from the market prices that price liberalization in 1986 allowed them to charge, rather than artificially suppressed prices they were forced to change under socialism (Fforde 2005, 1989). In provinces where SOEs provided the vast amount of revenue and jobs, 
they used their political influence to hamper reform that benefited the local private and foreign sectors. When stocks of FDI built up in particular provinces, it altered the dependence and subsequently the need to cater to the demands of SOEs and opened opportunities for experiments that historically would have encountered immediate resistance.

\section{Preferences of Central Actors}

It is paradoxical that in every one of the comparative examples of de facto decentralization cited in the introduction, provincial autonomy took place at the expense of the central government, yet the initial opening to the international economy that provided the spark for autonomy was always a central-level decision. Zweig put it best, “ “.. elite developmental strategies created the rules with which local governments, firms, organizations and individuals made their allocative decisions" (2002, 263-64).

This is certainly true of Vietnam. The Foreign Investment Law was passed one year after the 1986 Party Congress that christened the Doi Moi (renovation) economic reforms. Similarly, provincial autonomy was enhanced considerably in 1996 by two central-level legislative decisions in 1996. First, Decree 852 placed FDI coordination and planning under the direct control of the provincial People's Committee's Department of Planning and Investment (DPI). Second, the amended Foreign Investment Law allowed provinces to sign smaller FDI projects (below $\$ 10$ million; $\$ 40$ million in industrial zones) directly (VIR 1997).

Even though both of the 1996 decisions came after a great deal of provincial lobbying (VIR 1996) an important question remains unanswered: why would a rational and forward looking central government grant concessions which would eventually shift authority over key policy initiatives to certain provinces? If the central government, captured as it was by the dominant state-owned sector, could anticipate the consequences of FDI on the possibility of fence breaking in the provinces, it should have preempted this process from the beginning. More concretely, one should have never observed the building up of large surpluses in revenue from FDI at the provincial level at low thresholds of bargaining power. Central governments should have appropriated most of the surpluses when the bargaining power of the provinces was still relatively weak.

Jones-Luong explains this puzzle in Kazakhstan as the choice of a monolithic central leader (Nazerbayev), whose ultimate goal was the attraction of FDI, but who myopically failed to anticipate that, "regional leaders would transform this (i.e., the greatly expanded role of foreign investors) into greater authority for themselves over economic policy" (2003, 184). Similarly, Zwieg (2000) claims that initial central decisions to open the Chinese economy to the welfare benefits of FDI, while maintaining tight controls, created unanticipated new incentives for entrepreneurial local bureaucrats to evade central barriers to global transactions. Both arguments could certainly be applied to Vietnam; however, relying solely on the naivete or myopia of central actors in an empirical argument is quite limiting when generalizing to other contexts. I attempt to steer away from it by demonstrating that not cracking down on provincial experimentation may have resulted from the rational reliance of central actors on the revenue that fence breaking provinces produced.

Over the course of the 1990s, the Vietnamese Communist Party (VCP) had one primary incentive, which was to remain in power. This incentive manifested itself in three ordered preferences. First, power could only be maintained by focusing on economic growth and poverty alleviation. Emerging from the devastating economic crisis of the mid-80s, the primary goal was poverty alleviation for the citizens of one of the world's poorest countries (Fforde and de Vylder 1996; Van Arkadie and Mallon 2004). There was more than just altruism at work: with growth and redistribution to the most impoverished regions, the central officials hoped to maintain social order and thereby their grip on power. A booming population that introduced nearly a million new entrants to the workforce every year made this task more difficult.

Second, an emphasis was placed on central control over the reform process-growth was important, but officials in Hanoi wanted decision making to be in their hands. The 1992 Constitution does not mince words in proclaiming that the national administration is a centralized and unified system from the center to the local level, and the central government presides over that system. Moreover, in the Doi Moi era, some have claimed there was an attempt to recentralize the power of the central government through the redefinition of tasks and operational jurisdictions of local government (Vaskavul 2002)

Because initial growth after the 1986 reforms was to a large extent contributed by the state sector, large SOEs held increasing sway over central laws and their implementation at the provincial level. Indeed, the 1992 Constitution-that formally recognized the private sector-enshrined in law that the state sector was the core (nen tang) of the economy and should assume a "leading role" in it (Tonneson 2002). Consequently, the third preference of central officials was to preserve 
the state sector. There were also ideological reasons why the central government favored SOEs, including citizens' memories of the role of local SOEs in sustaining the populace during the war with the United States.

Support for the state sector, however, often took a back seat to social order brought about by economic growth. Whenever SOEs could not adequately supply revenue-either due to inefficiency or corruptiontheir capture of the central government diminished and voices rose calling for switching allegiance to economic sectors that could better deliver economic growth (Vaskavul 1997; Vuving 2006). Ideally, central officials would have preferred a fast growing state sector during the 1990s, allowing them the ability to maintain social order and their tight control over the economy. But as FDI began to blossom in certain areas of the country and beneficiary provinces began to push against the confines of central laws, central officials concluded that growth was preferable to support for the state sector in those regions.

As discussed above, only eight provinces routinely ran fiscal surpluses throughout the 1990s, but together they accounted for about $70 \%$ of national revenue. Other provinces were frequent recipients of transfers from the central government, allowing a higher level of service delivery than they could finance out of their own revenue. In addition to block grants for national health and education programs, these cash transfers have played an increasingly important role in leveling per capita expenditures nationally (GVDWG 2000). While the average per capita GDP of rich provinces has been three times that of low-income provinces since 1996, per capita expenditure has been only $57 \%$ higher (World Bank 1996). Some authors have gone so far as to credit the redistribution mechanism for Vietnam's acclaimed poverty reduction from $70 \%$ of the population living on less than 2,100 calories in 1990 to $29 \%$ by 2002 (Bird, Litvak, and Rao 1995).

Because most FDI entered a handful of provinces, their participation in redistribution and poverty alleviation granted them an inordinate amount of bargaining power with central authorities, making it very difficult to discipline fence breakers openly for violating central law. Moreover, throughout the 1990s and until 2006, the central government did not actually possess the formal authority to dismiss provincial officials (Vietnamnet 2006a, 2006b). Replacing Provincial People's Committee Chairman took place but necessitated the cumbersome pathways of pursuing criminal charges against the official or working through the Party cadre system to revoke their membership in the VCP (Dung 2001). Both channels became increasingly difficult when dealing with economically powerful provincial leaders, who had cultivated alliances based on their munificence.

Seen in this light, the Vietnamese Central Government's maintenance of revenue targeting makes a great deal of sense. As with the Chinese revenue-sharing arrangements before 1994, from the standpoint of the center, financial targeting was attractive because it gave provincial governments a stake in their economies and promised to enhance national revenues (Echeverri-Gent 2000; Shirk 1993). But preserving political power through central control was of highest priority, so central officials were reluctant to fully embrace the provincial experiments. Instead, they allowed local fence-breaking experiments to continue in economically powerful provinces, but simultaneously used state-owned newspapers to condemn those experiments and deter weaker provinces from following suit (Porter 1993) - a fact I exploit to construct my dependent variable of local autonomy. The result was a series of autonomous incidents in fortunate provinces, but very little in the way of a national policy of decentralization.

Thus, even under the restrictive assumption of a monolithic central government, a rational decision could have been made to allow inflows of FDI knowing full well that it would lead to local autonomy in some areas. The large number of provinces unable to attract FDI, however, became even more dependent on transfers and state-led investment financed by high return in the globally integrated regions.

A number of scholars argue, however, that a monolithic central government never existed in Vietnam and that policy debates often boiled down to factional cleavages between reformers and conservatives in the central government. Even the initial opening of the Vietnamese economy to the world, they claim, resulted from cooperation between central-level reformers and some provincial leaders. Divisions at the central level provided another opening for provincial fence breaking (Abrami 2004; Riedel and Turley 1998). Because SOEs were resistant to economic openness which threatened their privileged position, a group of modernizers led by Prime Minister Vo Van Kiet and Nguyen Co Thach, the Foreign Minister and Politburo member, drawing on the Chinese experience, began to argue for economic interdependence as a strategy to keep Vietnam from lagging behind other developing countries (Vuving 2006). In an anonymous memo, Kiet called for openness toward the international economic system and urged the VCP to capitalize on the propitious international environment for attracting investment and expanding 
exports (Vaskavul 1997). At the same time, Kiet, like his mentor Nguyen Van Linh, was aware of and may have even tacitly encouraged provincial-level experimentation on economic reforms (Turley and Womack 1998).

While these experiments were in no way officially sanctioned, there is reason to believe that central leaders like Kiet and Linh may have looked the other way as fence breaking occurred. For these reformers, criticism by the state-owned press offered the dual benefit of limiting the spread of fence-breaking efforts and appeasing conservative leaders who were opposed to them without actually bringing the provincial experiments to a halt. Acknowledging that certain central actors may have tacitly approved of experimentation, however, should not obscure the larger argument of de facto decentralization; policy authority was indeed being shifted to fence-breaking provinces outside of any official legislation. Only much later would some experiments be codified into central laws such as the Land, Enterprise, and Public Administration Reform Laws. Secondly, reformers, despite their actions, were not the dominant authorities in the central government. In fact, throughout most of the 1990s, they were on the losing side of economic reform debates (Malesky 2006; Tonesson 2002; Vaskavul 1997; Vuving 2006). Tacitly encouraging provincial experimentation was but one of several methods they were using to chip away at the dominant coalition of SOEs and conservative ideologues. This was enabled by large concentrations of FDI stocks in particular provinces that helped empower the fence breakers.

\section{Testing the Impact of FDI on Fence-Breaking Activity}

In this section, I develop a statistical test of the hypothesis that the larger the stock of FDI as a percentage of its economy, the more likely a province is to engage in fence-breaking economic reforms.

\section{Dependent Variable-Content Analysis of Autonomy}

The dependant variable in this analysis is whether the province has engaged in an autonomous action in a

\footnotetext{
${ }^{7}$ The five Vietnamese and one English language paper selected were: Nhan Dan (ND: People's Daily), Lao Dong (LD: Labor), Sai Gon Giai Phong (SGGP: Liberated Saigon), Tuoi Tre (TT: Youth), Thanh Nien (TN: Young People), and the Vietnam Investment Review (VIR). For a detailed description of the newspaper selection process see online Appendix 1.
}

given year regarding economic policy, measured by a content analysis of state-owned Vietnamese newspapers. ${ }^{7}$ I tracked six daily newspapers from 1990 to 2000 and recorded every time a province was cited for willfully pushing beyond central economic or administrative policy (red lights), such as allowing land to be used as collateral in receiving bank loans, ${ }^{8}$ and every time provinces took advantage of ambiguity in central law to enact their own economic reforms (yellow lights). ${ }^{9}$ After selection, these incidents were organized into 13 categories. ${ }^{10}$

The universe of cases was limited to the economic arena. Thus, autonomous incidents such as changes in marriage regulations and more lenient policies toward the content of literary journals were excluded. Also excluded were cases where lower-level subnational leaders (from the district or commune level) violated central laws, as it was not clear that these were sanctioned by their provincial overseers. Finally, centrally sanctioned policy experiments were dropped, because they did not reflect true autonomy. While a case could be made that provinces lobbied to receive the experimental status, there was a possibility that central officials chose pilot locations for reasons other than their bargaining power. In addition, many of these cases of green lights were actually belated central sanctioning of earlier fence-breaking incidents already captured in the content analysis. The geographical spread of fence-breaking incidents is shown in Figure 1 (Panel B).

There are literally hundreds of different national and local newspapers and magazines in Vietnam written for a range of different constituencies. While all are officially state-owned papers and select articles within the parameters set by the VCP, they are often published by different government agencies or provincial governments. Due to time and budget constraints, a decision was made to limit the content analysis to only six

\footnotetext{
${ }^{8}$ This reform was first initiated in 1993 by Ba Ria-Vung Tau. After a few months, it was determined that the province had gone too far and the experiment was supposed to be stopped (SGGP 1993a). While there was a brief halt, eventually the reform gained support in other provinces (LD 1993).

${ }^{9}$ In HCMC, the Department of External Economic Relations actually began putting limits on the amount of export taxes placed on products produced within its boundaries (SGGP 1991). They also violated central customs laws by clearing goods from inspection before assessing import taxes (SGGP 1993b).

${ }^{10}$ These include: investment incentives, land use rights, legal reform, administrative policies, micro-economic policies, infrastructure, trade policies, environmental policies, labor policies, taxes, investment zones, credit funds, treatment of foreigners, and sociocultural policies related to business (i.e., allowable musical selection in Karaoke establishments). See Malesky (2004) for more details on the content analysis approach.
} 
papers with nationwide circulations as opposed to provincial papers, but it was important to select these papers in a way that maximized variance on the dependent variable without introducing any biases into the newspaper coverage. Overall, 550 articles were chosen that span every one of Vietnamese provinces, although many provinces did not have any cases in a particular year.

Of course, there are several limitations to such an approach. First, the two major metropolises of HCMC and Hanoi tended to be cited more than other provinces, simply because of their special importance to the country. We might expect that smaller, less endowed provinces may receive less attention from newspapers for the same reasons that investors might ignore them. To control for this, I include a dummy variable to account for the special importance of these two cities and control for overall size of provincial GDP per capita in the regression analysis.

Secondly, it is often not clear whether a provincial leader has simply broken a fence or is actually engaging in corruption, as the papers often allege. Many reform endeavors offer some personal gain to the provincial leaders or their families as discussed above; for instance, a leader that allows inputs to be imported below the tariff price, but whose family is heavily invested in the recipient industry. Authors have noted that trumped up corruption cases are often used to reign in autonomous provinces, so one cannot simply rule these out (Gainsborough 2001, 2003). To account for this dilemma, I subdivided the dataset into cases of pure economic reform and those in which members of the People's Committee benefited monetarily from the initiative, such as through the sale of houses, land, or imported goods. These cases of tentative "corruption" account for about one-third of the entire sample of cases. Results did not vary significantly between the cumulative dataset and a dataset only including cases where no individual gain was recorded.

Third, some analysts of Vietnam have noted that the central government may not bark at a particular reformist province for fear that its innovations will become popular and spread (Porter 1993). My data set simply misses these occasions, as provinces must be cited to appear, necessitating further qualitative case studies of a subset of provinces. As unrecognized cases of fence-breaking bias against a positive finding for my theory, a positive relationship between FDI and autonomy should be considered an indication that actual cases of fence breaking are even higher.

I use a dummy of whether a province has engaged in fence breaking in a given year as my dependent variable, because I believe that full count of autonomy offers too easy a victory for my theory. The strong correlation (.62) between stock of investment and the stock of autonomous actions in 1996 (the midyear in the time series and before the 1997 creation of seven new provinces) can be seen in the scatter plot in Figure 2.

Three additional reasons underlie my decision to employ a dichotomous variable. First, severe nonstationarity in both the count variable (provinces are becoming more autonomous over time) and stocks of FDI may lead to spurious regression (Granger and Newbold 1974; Kennedy 1993). A Hadri Lagrange multiplier test revealed that the null hypothesis of stationarity cannot be rejected in the dichotomous measure (cases of autonomy), but can be rejected in the count measure of stock of autonomy, where the test statistics are not significantly different from zero in balanced panels (Hadri 2000). Because of the difficulties of adequately testing for co-integration (Engle and Granger 1987) in an unbalanced panel setting, I choose the conservative correction to nonstationarity of first differencing all trending variables (including implemented FDI and many of the control variables). These variables should be interpreted as changes rather than levels. ${ }^{11}$

Secondly, cases of autonomy in a given year are not independent of one another. A series of fencebreaking incidents in a given province are likely to be related to some underlying and unobservable need of foreign investors or even an idiosyncratic factor such as a particularly audacious provincial official. Newspaper coverage of these incidents is also not an independent draw; it is quite common to see clusters of articles on different violations of the Land Law cited in local newspapers because journalists were primed to seek out those stories. Third, clusters of cases are found most often in the biggest provinces leading to severely skewed data. By reducing the measure to a dichotomous variable of whether fence breaking was observed or not, I am able to skirt these issues and focus on the central question of how much FDI is needed for a province to challenge central authority for the first time that year.

The data set for this test includes pooled time series data on unbalanced panels, due to the increase in Vietnamese provinces over time. 1990 is chosen as the starting date, because reliable data on implemented FDI as opposed to merely contracted investments does not exist before that date. 2000 was

\footnotetext{
${ }^{11}$ See online Appendix 4 for Hadri Lagrange Multiplier tests of nonstationarity.
} 


\section{Figure 2.}

Scatter Plot of Total Autonomous Incidents and Total FDI Stock

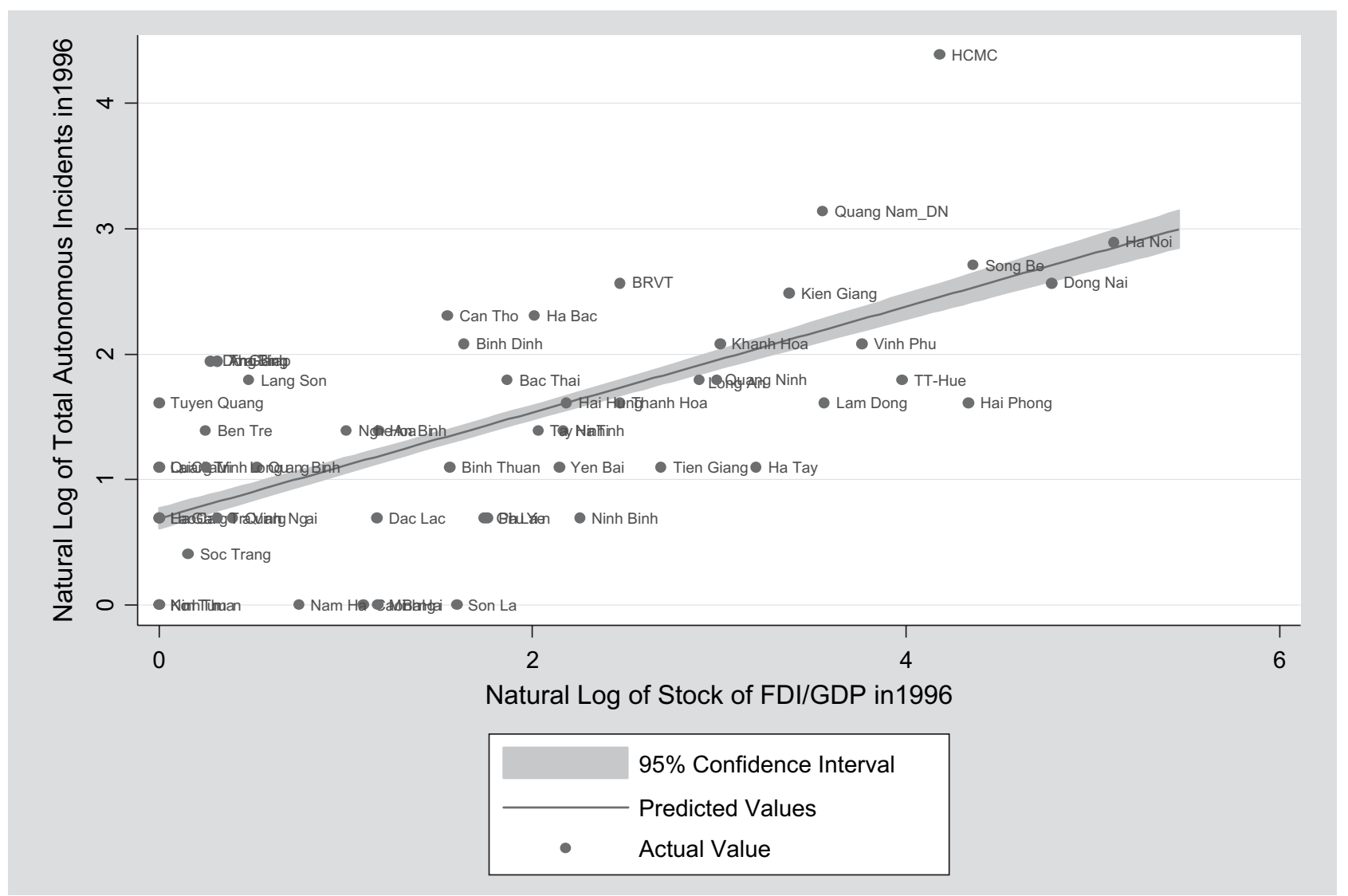

chosen as the end point, because it represents to many scholars the final year of SOE capture of the central government when the Enterprise Law significantly reduced the restrictions on private sector entry into the market (Thayer 2002; Van Arkardie and Mallon 2003).

\section{Causal Variable: FDI in Vietnam-Stock of Implemented FDI as a percentage of Provincial GDP}

The causal variable is the stock of implemented FDI as a percentage of GDP for every province between 1990 and 2000, allowing for depreciation over a 10year lifespan of each new investment (GSO 2001). Vietnamese datasets report both contracted FDI (the full amount of the project proposed by the firm when it receives its investment license) and implemented FDI (the amount of FDI actually disbursed in the province). Investors generally disburse the contracted amount of investment incrementally to hedge against political risk. As a result, the amount of implemented
FDI in a province can sometimes be as little as half the licensed amount, which may never be reached (Freeman and Nestor 2004; Mai 2004). In addition, some investors had overly optimistic expectations about Vietnam's potential in the early '90s and signed licenses with irrational investment sizes, from which they eventually retreated (Kokko, Kotoglu, and Krohwinkel-Karlsson 2003). For the purposes of my analysis, I use implemented FDI in order to focus on the actual lobbying strength of investors, based on how much money was already spent, and not the highly speculative potential lobbying strength. Finally, in one regression model, the lagged stock of FDI is used to control for economies of agglomeration, as the economics literature indicates that investors cluster near other investors to benefit from vertical linkages as well as the fact that the presence of other successful investors can be used as an information shortcut (Krugman 1993). ${ }^{12}$

\footnotetext{
${ }^{12}$ Model 7 (Tables 2 and 3) and Model 5 (Tables 4 and 5).
} 
Many authors have noted that different types of investors have different goals. While export-oriented investors need improvements in institutional quality to lower their transactions costs and facilitate the competitiveness of their products on international markets, investors interested only in accessing the domestic market might actually push for more opaque governance to protect their market position (Fung et al. 2002; Kobrin 1987). While undoubtedly important, measurement complexities (exports are usually assessed at ports rather than provincial capitals) and a limited time series (only 1997-2000, where three years were during the Asian Financial Crisis), require that a thorough analysis of this issue be reserved for future work.

\section{Exogenous Control Variables}

Three types of control variables are utilized in the simultaneous equation model: variables theoretically affecting both FDI and autonomy; variables influencing only FDI; and variables only having an effect on autonomy. The latter two categories are particularly important in a simultaneous model, because they make the system of equations soluble. As in an instrumental variables model, these variables must be chosen with adherence to a set of assumptions known as exclusion restrictions. In short, these variables should be significantly correlated with the dependent variable in their respective regressions and uncorrelated with the error term in the equation explaining the other dependent variable. Because this is a panel data set, it is also preferable that these variables vary over time. Unless one of these "instruments" in each equation is significant, the system is not identified and the endogeneity problem has not been solved.

\section{Variables Employed in Both Equations}

Infrastructure. I employ a factor analysis to create a composite measure of three different measures of infrastructure. These include the number of telephones in the province and the amount of transported material (in millions of tons) per kilometer to gauge the quality of infrastructure throughout the period, and the percentage of population in urban versus rural areas. The procedure yielded one component. Table 1 below includes the factor loadings. I calculate infrastructure only in the first year of a province's creation to avoid endogeneity with FDI. Infrastructure theoretically affects both sides of the simultaneous model. Provinces with infrastructure at the beginning of the period are likely to attract more FDI (Kokko, Kotoglu, and Krohwinkel-Karlsson 2003), but it is also possible that initial conditions may shape the policy positions of provincial leaders. Leaders of provinces with a relatively good infrastructure would have more to gain from pro-investor policies, whereas leaders of province with poor infrastructure would have no such illusions (Shirk 1994; Zweig 2002).

City Dummy. This variable simply captures whether the province is Hanoi or HCMC to account for both their unique investment attraction and possible biased coverage in newspapers focused on the two metropolises.

Southern Dummy. It is open debate whether southern provinces had a special advantage in leading the reform agenda and attracting investment early on in the 1990s. They benefited from a southern legacy and affinity with a market mechanism. Because southern provinces were only under a centrally planned system for 11 years (between 1975 and 1986), many of the entrepreneurs under the old regime reemerged after the beginning of economic reforms. To capture the unique influence of the South, I create a dummy variable based on whether a province was located north or south of the 1954 Geneva Armistice's border declaration at the $17^{\text {th }}$ Parallel.

GDP per capita. The natural log of provincial GDP per capita is used in later specifications to control for the fact that both investment and newspaper coverage may be a function of provincial wealth. GDP also serves as a proxy for the relevant market size for investors in cross-national studies of FDI (Jensen 2003). ${ }^{13}$

\section{Variables Employed only in the Equation Explaining FDI.}

Distance from Hanoi or HCMC in kilometers is a measure of whether foreign investors are interested in accessing large urban markets for sales, purchase of intermediate goods, and softer factors such as the presence of other foreigners and services catering to their needs (i.e., international hospitals and schools).

Population Size is used to control for the size or the intraprovincial market. It is a popular control variable in the literature on international determinants of investment (Jensen 2003; Markusen 1998).

\footnotetext{
${ }^{13}$ Government consumption is also cited in many cross-national studies, but is not available in provincial-level data for the entire time series.
} 
TABLE 1. Factor Analysis of Infrastructure Variables (Without Rotation)

\begin{tabular}{lcc}
\hline Variable & Factor 1 & Uniqueness \\
\hline $\begin{array}{l}\text { Percentage of population } \\
\quad \text { urban }\end{array}$ & 0.8859 & 0.2151 \\
$\begin{array}{l}\text { Telephones per capita } \\
\text { Million Tons of cargo }\end{array}$ & 0.8285 & 0.3137 \\
$\quad$ transported on provincial & 0.8255 & 0.3185 \\
$\quad$ roads per km & & \\
$\quad$ Eigenvalues & 2.15 & \\
Cumulative Variance & $72 \%$ & \\
\hline
\end{tabular}

Data obtained from 10 Cuoc Dieu Tra Quy Mo Lon 1998-2000. 2001. [10 Large Scale Surveys 1998-2000. Hanoi: Nha Xuat Ban Thong Ke [Statistical Publishing House]; Nien Giam Thong Ke [Statistical Yearbook of the General Statistical Office] 1995-2002 (multiple volumes). Hanoi: Nha Xuat Ban Thong Ke [Statistical Publishing House].

Population sizes vary from about 270,000 in the Northern Bac Kan to over 5 million in HCMC.

Asian Financial Crisis. This is a dummy variable for the years 1998 and 1999, when FDI fell as a result of the financial crisis among Vietnam's primary investors (Masina 2004). If the crisis had any effect on autonomy, it was because of the reduction of FDI.

Agricultural output as a percentage of provincial $G D P$. Early investors tended to be attracted to minerals, light manufacturing, and tourism, while avoiding investing in heavily agricultural areas. As a result, it is necessary to control for the level of development and preexisting manufacturing base. Agricultural importance in the economy provides a nice proxy.

Secondary School. Ideally, the percentage of secondary school graduates in the labor force would serve as measure of human capital that could be employed in a model attempting to explain investment attraction. The literature suggests that investors are motivated to locate in areas with the most highly trained labor force (Helpman 2004). Unfortunately, the measure of secondary school graduation in Vietnam is an odd measure, perhaps capturing an entirely different process. It is negatively correlated with provincial GDP $(-.20)$ per capita and highly negatively correlated with distance from Hanoi $(-.50)$. These relationships make sense to Vietnam watchers, because particular provinces (especially those in the Central Coast) which played important roles in the Communist revolution, were favored by the central regime, but their education was likely to be highly tinged with MarxistLeninist thought. As Vietnam's adult literacy rate in
1990 was $94 \%$ according to the World Bank's World Development Indicators (2004), investors had the luxury of knowing workers had basic capacity no matter where they located. Thus, we should expect that rather than being attracted to indoctrinated workers, investors would prefer less-educated workers who they could train de novo. It is unlikely that secondary school graduation rates had an independent effect on autonomy, however, because it is provincial leaders rather than the general populace who make fencebreaking decisions. For most of the time period under investigation, these leaders tended to have very similar biographical profiles despite their different birthplaces. Most served some time in the military and experienced secondary and often tertiary education in a Marxist-Leninist System, often studying abroad in the Communist Bloc (Gainsborough 2004).

\section{Variables Employed only in the Equation Explaining Autonomy}

Years after Party Congress. Controls for the time in years that has passed since the Party Congress, which take place every five years. Because provincial leaders are empowered by the selection to the Central Committee that takes place at these Congresses, they may be unwilling to rock the boat with any fence breaking immediately before a new Congress. Years is not included as a determinant of FDI because the evidence suggests that investors pay little attention to the VCP calendar. In 2006, Intel decided on a $\$ 300$ million semiconductor operation in HCMC only weeks before the $10^{\text {th }}$ Party Congress (Taipei Times 2006). Bivariate correlations bear out this assessment, Years has a significant and positive correlation with autonomy (0.16) and an insignificant relationship with FDI (0.0072).

Cabinet Member from Province. There is much debate in Vietnam about how political connections to central officials shield provinces from serious punishment when they experiment with reforms (Kerkvliet 2001; Turley and Womack 1998; Vasavakul 2003). For China, Landry $(2002,2004)$ tested the validity of these statements by measuring whether promotions to central positions results from informal networks at the central level, finding little support for the conjecture. Similarly, I control for the number of cabinet positions in each year held by provincial compatriots. The number ranges from 0 in the case of the majority of provinces to 8 for Nghe An (the birth place of Ho Chi Minh) in 1997. 
Strength of Party Control. Sheng (2007) has argued convincingly that Chinese provinces more exposed to global economic forces may have a tendency to pursue a different economic reform trajectory, but that the central government is not a passive actor, rather it maneuvers to maintain control of subnational governments through the personnel appointment process-shifting centrally connected Party Secretaries to lead more open provinces. He measures this impact by using a 4-point scale pioneered by Huang (1996) recording Party control over provincial governments by the career history of the provincial Party Secretary:

4: The Provincial Party Secretary holds a concurrent central position.

3: A Central Minister or Vice Minister was transferred to lead the province.

2: A Provincial Party Secretary from another locality was transferred to lead the province.

1: The Party Secretary has never held a government position outside of his province.

I duplicate this 4-point measure and, following Sheng, hypothesize that it should be negatively associated with autonomy.

Province is the Result of Previous Separation. Vietnam has created 24 new provinces since 1990. There is a strong possibility that due to the patronage politics involved in the creation of new boundaries and the construction of new offices and infrastructure, leaders of newly created provinces may be less able to act autonomously than their counterparts in long-standing provinces (Malesky 2006).

Net Regional Autonomy. Market Preserving Federalists believe that other provinces should imitate successful reforms (Montinola, Qian, and Weingast 1995). Following the recent work on policy diffusion, however, this will be tempered by province's knowledge of provincial reforms in its neighboring provinces (Kopstein and Reilly 2000; Simmons and Elkins 2004). We should expect that policy ideas should spread to neighboring provinces and should diffuse more rapidly across provinces of similar geography, climate, and topology. Following the GSO, I divide Vietnam into eight regions based on geographic and climatic characteristics. To measure whether there has been a diffusion of reforms, I measure the mean number of autonomous actions of provinces within the region of the tested province minus the stock of autonomous incidents occurring in the province over the same period. The assumption is that the higher the number of reforms in neighboring provinces, the more likely diffusion will take place.

\section{Results}

The results of a pooled naïve models which do not account for endogeneity are shown in Model 1 of Tables 2 and 3, respectively, where it is clear that FDI has a significant impact on fence-breaking actions and incidents of local autonomous actions have a significant effect on FDI attraction. While fascinating, these results are highly suspect due to endogeneity. Which actually comes first-FDI or autonomous incidents?

To deal with the endogeneity, I use a simultaneous equation model of autonomy in the Vietnamese provinces between 1990 and 2000 using the CDSIMEQ program (Keshk 2003) and correcting for bias using an asymptotically correct covariance matrix (Maddala 1983). Further corrections to standard errors were made prior to analysis to deal with cross-sectional time-series properties of the data (Beck and Katz 1995).

The model begins with two equations:

$$
\begin{aligned}
& y_{1}=\gamma_{1} y_{2} *+\beta_{1}^{\prime} \mathbf{X}_{1}+\varepsilon_{1} \\
& y_{2}=\gamma_{2} y_{1} *+\beta_{2}^{\prime} \mathbf{X}_{2}+\varepsilon_{2}
\end{aligned}
$$

Where,

$y_{1}$ is the stock of FDI per capita within each province every year, a continuous endogenous variable,

$y_{2}$ is a dichotomous endogenous variable capturing whether one or more cases of fence breaking were observed in a given year in a given province. The variable receives a scores of 1 if $y_{2}>0$, and 0 otherwise, $\mathbf{X}_{1}$ and $\mathbf{X}_{2}$ are matrices of exogenous variables in (1) and (2)

$\beta_{1}^{\prime}$ and $\beta_{2}^{\prime}$ are vectors of parameters in (1) and (2), $\gamma_{1}$ and $\gamma_{2}$ are the parameters of the endogenous variables in (1) and (2),

$\varepsilon_{1}$ and $\varepsilon_{2}$ are the error terms of (1) and (2).

Model 2 (Restricted) of Tables 2 and 3 shows the first stage regressions with only variables that apply to both models. By comparing Model 2 to the other models in the table, readers can ascertain the individual impact of adding variables which apply uniquely to FDI and Fence Breaking, respectively, and can verify that all of the excluded variables have strong independent effects on the two dependent variables. In the FDI equation, only the Asian Financial Crisis is not statistically significant. In the Fence-Breaking equation, only Party Control is not significant (number of compatriots is significant at the 0.10 level). F-tests verify that the joint inclusion of both of sets of control variables significantly affects variation in the respective dependent variables. Therefore, these tests satisfy the exclusion 
TABle 2. Naïve, Restricted, and First Stage Models of Determinants of Foreign Direct Investment (With Panel Corrected Standard Errors)

\begin{tabular}{|c|c|c|c|c|c|c|c|}
\hline $\begin{array}{l}\text { Dependent } \\
\text { Variable = Stock } \\
\text { of FDI / GDP (fd) } \\
\text { (Continuous Variable) }\end{array}$ & $\begin{array}{l}\mathrm{Naïve}^{\dagger} \\
(1)\end{array}$ & $\begin{array}{l}\text { Restricted } \\
\text { (2) }\end{array}$ & $\begin{array}{l}\text { 1st Stage }{ }^{\psi} \\
(3)\end{array}$ & $\begin{array}{c}\text { Geo } \\
\text { Dummies }^{\psi} \\
(4)\end{array}$ & $\begin{array}{c}\text { Diffusion }^{\psi} \\
\quad(5)\end{array}$ & $\begin{array}{c}\text { Size of } \\
\text { Economy } \\
(6)\end{array}$ & $\begin{array}{c}\text { Lagged } \\
\text { FDI } \\
\text { Equation } 1^{\psi} \\
(7) \\
\end{array}$ \\
\hline $\begin{array}{l}\text { Case of Fence- } \\
\text { Breaking }\end{array}$ & $\begin{array}{l}1.856^{*} \\
(0.71)\end{array}$ & & & & & & \\
\hline $\begin{array}{l}\text { Distance from } \\
\text { major market }\end{array}$ & $\begin{array}{c}-0.00368^{*} \\
(0.0015)\end{array}$ & & $\begin{array}{c}-0.00425^{\star} \\
(0.0015)\end{array}$ & $\begin{array}{c}-0.00397^{\star} \\
(0.0016)\end{array}$ & $\begin{array}{c}-0.00397^{\star} \\
(0.0016)\end{array}$ & $\begin{array}{c}-0.00346^{*} \\
(0.0016)\end{array}$ & $\begin{array}{r}-0.00206 \\
(0.0015)\end{array}$ \\
\hline $\begin{array}{l}\text { Population in } \\
10000 \text { s (fd) }\end{array}$ & $\begin{array}{c}0.208 \\
(0.11)\end{array}$ & & $\begin{array}{l}0.225^{*} \\
(0.11)\end{array}$ & $\begin{array}{c}0.145 \\
(0.11)\end{array}$ & $\begin{array}{r}0.145 \\
(0.11)\end{array}$ & $\begin{array}{r}0.152 \\
(0.11)\end{array}$ & $\begin{array}{r}0.119 \\
(0.11)\end{array}$ \\
\hline $\begin{array}{l}\text { Agriculture } \\
\text { Output/GDP (fd) }\end{array}$ & $\begin{array}{r}-0.058^{\star} \\
(0.016)\end{array}$ & & $\begin{array}{c}-0.0465^{\star} \\
(0.016)\end{array}$ & $\begin{array}{c}-0.0461^{\star} \\
(0.016)\end{array}$ & $\begin{array}{c}-0.0461^{\star} \\
(0.016)\end{array}$ & $\begin{array}{c}-0.0472^{\star} \\
(0.016)\end{array}$ & $\begin{array}{c}-0.0308^{\star} \\
(0.015)\end{array}$ \\
\hline Infrastructure (Year 1) & $\begin{array}{l}2.233^{*} \\
(0.94)\end{array}$ & $\begin{array}{r}0.555 \\
(0.93)\end{array}$ & $\begin{array}{l}2.622^{\star} \\
(0.91)\end{array}$ & $\begin{array}{r}0.984 \\
(0.83)\end{array}$ & $\begin{array}{c}0.984 \\
(0.83)\end{array}$ & $\begin{array}{r}0.765 \\
(0.87)\end{array}$ & $\begin{array}{r}0.421 \\
(1.19)\end{array}$ \\
\hline $\begin{array}{l}\text { Years of Asian } \\
\text { Financial Crisis }\end{array}$ & $\begin{array}{c}-0.546 \\
(0.75)\end{array}$ & & $\begin{array}{r}-0.126 \\
(0.79)\end{array}$ & $\begin{array}{l}0.00619 \\
(0.78)\end{array}$ & $\begin{array}{l}0.00619 \\
(0.78)\end{array}$ & $\begin{array}{c}-0.0659 \\
(0.78)\end{array}$ & $\begin{array}{l}-1.237 \\
(0.78)\end{array}$ \\
\hline $\begin{array}{l}\% \text { of secondary school } \\
\text { graduates }(\mathrm{fd})\end{array}$ & & & $\begin{array}{c}-0.0884^{*} \\
(0.029)\end{array}$ & $\begin{array}{c}-0.0875^{\star} \\
(0.028)\end{array}$ & $\begin{array}{c}-0.0875^{\star} \\
(0.028)\end{array}$ & $\begin{array}{c}-0.0875^{\star} \\
(0.028)\end{array}$ & $\begin{array}{c}-0.0881^{\star} \\
(0.028)\end{array}$ \\
\hline $\begin{array}{l}\text { Stock of per capita } \\
\quad(\mathrm{fd})(\operatorname{lag} 1)\end{array}$ & & & & & & & $\begin{array}{l}0.473^{\star} \\
(0.11)\end{array}$ \\
\hline City Dummy & & $\begin{array}{l}6.713^{\star \star} \\
(3.37)\end{array}$ & & $\begin{array}{l}5.635 \\
(3.43\end{array}$ & $\begin{array}{r}5.635 \\
(3.43)\end{array}$ & $\begin{array}{c}5.504 \\
(3.42)\end{array}$ & $\begin{array}{r}3.512 \\
(3.90)\end{array}$ \\
\hline Southern Dummy & & $\begin{array}{c}0.453 \\
(0.58)\end{array}$ & & $\begin{array}{l}1.191^{\star} \\
(0.64)\end{array}$ & $\begin{array}{l}1.191^{*} \\
(0.64)\end{array}$ & $\begin{array}{c}0.955 \\
(0.70)\end{array}$ & $\begin{array}{l}1.097 \\
(0.69)\end{array}$ \\
\hline $\begin{array}{l}\text { Natural Log of GDP } \\
\text { per Capita (fd) }\end{array}$ & & 1.126 & & & & $\begin{array}{c}0.555 \\
(0.76)\end{array}$ & $\begin{array}{r}-0.744 \\
(0.74)\end{array}$ \\
\hline Constant & $\begin{array}{l}3.456^{\star} \\
(0.91)\end{array}$ & $\begin{array}{l}1.252 \\
(0.85)\end{array}$ & $\begin{array}{l}4.396^{\star} \\
(0.88)\end{array}$ & $\begin{array}{c}2.758^{\star} \\
(0.74)\end{array}$ & $\begin{array}{c}2.758^{\star} \\
(0.74)\end{array}$ & $\begin{array}{l}2.235^{\star} \\
(0.96)\end{array}$ & $\begin{array}{c}1.866 \\
(1.15)\end{array}$ \\
\hline Observations & 503 & 503 & 503 & 503 & 503 & 503 & 425 \\
\hline R-squard & 0.10 & 0.08 & 0.09 & 0.11 & 0.11 & 0.11 & 0.30 \\
\hline
\end{tabular}

All models assume panel-specific AR1 process and panel-level heteroskedatic errors (Standard errors in parentheses)

${ }^{\star}$ Indicates significance at the .05 level (two-tailed test)

(lag1) lagged 1 year; (fd): indicates the first difference of variable taken.

$\dagger$ Naïve regression indicates regression that does not address endogeneity.

$\ddagger$ Restricted model includes only variables also used in equation 2 - the determinants of provincial fence-breaking behavior.

$\psi$ First stage of two-stage simultaneous equation model.

restriction for instrumental variables and allow me to proceed to analysis of the simultaneous model. ${ }^{14}$

Tables 4 and 5 below illustrates the results of the simultaneous model. Five models are displayed in each table. Model 1 is a baseline model using the key

\footnotetext{
${ }^{14}$ As a further check of the validity of the instruments used in the model, an exogeneity test of fence breaking was performed following Alvarez and Glasgow (2000). The second-stage regression was rerun with the residuals from the first-stage regressions in Model 3 of Tables 2 and 3. A likelihood ratio test (lrtest) was performed on the estimates the models (one including the residual and one without). The lrtest statistic on the model was -.38 with $\mathrm{p}$. value of 1.00 indicating that there is no correlation between first-stage residuals and outcomes in the second stage, which further confirms the use of instruments. Please see online Appendix 5.
}

dependent variables of FDI and cases of fence breaking along with the standard controls implied by the literature. Model 2 includes the dummy variables for cities and for southern provinces. Model 3 adds the regional autonomy measures to capture diffusion. Model 4 uses the log of GDP per capita to control for the economic importance of the province. Finally Model 5 uses the lagged stock of FDI to capture economies of agglomeration.

Narrowing our lens on equation (1) in Table 4, it seems quite clear that the original speculation about the mutually reinforcing impact of FDI and cases of provincial autonomy proved untrue. While FDI increases the probability of autonomous incidents in every model, cases of fence breaking do not have 
TABle 3. Naïve, Restricted, and First Stage Probit Models of Determinants of Fence-Breaking Behavior (With Standard Errors Clustered at Panel Level)

\begin{tabular}{|c|c|c|c|c|c|c|c|}
\hline $\begin{array}{l}\text { Dependent Variable }= \\
\text { Case of Fence-Breaking } \\
\text { (Dichotomous Variable) }\end{array}$ & $\begin{array}{l}\text { Naïve }^{\dagger} \\
(1)\end{array}$ & $\begin{array}{c}\text { Restricted } \\
\text { (2) }\end{array}$ & $\begin{array}{l}\text { 1st Stage }{ }^{\psi} \\
\text { (3) }\end{array}$ & $\begin{array}{c}\text { Geo } \\
\underset{(4)}{\text { Dummies }} \psi\end{array}$ & $\begin{array}{c}\text { Diffusion }^{\psi} \\
\quad(5)\end{array}$ & $\begin{array}{c}\text { Size of } \\
\text { Economy } \\
(6)\end{array}$ & $\begin{array}{c}\text { Lagged } \\
\text { FDI } \\
\text { Equation } 1^{\psi} \\
(7)\end{array}$ \\
\hline Stock of FDI/GDP (fd) & $\begin{array}{r}0.0207^{*} \\
(0.0089)\end{array}$ & & & & & & \\
\hline $\begin{array}{l}\text { Province the Result of } \\
\text { Separation }\end{array}$ & $\begin{array}{r}-0.160 \\
(0.13)\end{array}$ & & $\begin{array}{c}-0.335^{\star} \\
(0.13)\end{array}$ & $\begin{array}{c}-0.323^{\star} \\
(0.13)\end{array}$ & $\begin{array}{c}-0.353^{\star} \\
(0.15)\end{array}$ & $\begin{array}{r}-0.254 \\
(0.15)\end{array}$ & $\begin{array}{c}-0.254 \\
(0.15)\end{array}$ \\
\hline $\begin{array}{l}\text { Number of Compatriots } \\
\text { in Cabinet }\end{array}$ & $\begin{array}{l}0.106 \\
(0.066)\end{array}$ & & $\begin{array}{c}0.114 \\
(0.065)\end{array}$ & $\begin{array}{c}0.113 \\
(0.067)\end{array}$ & $\begin{array}{c}0.153 \\
(0.079)\end{array}$ & $\begin{array}{r}0.169^{\star} \\
(0.077)\end{array}$ & $\begin{array}{r}0.169^{*} \\
(0.077)\end{array}$ \\
\hline $\begin{array}{l}\text { Party Control of } \\
\text { Provincial Leader }\end{array}$ & $\begin{array}{r}0.0103 \\
(0.091)\end{array}$ & & $\begin{array}{r}0.0767 \\
(0.086)\end{array}$ & $\begin{array}{c}0.0646 \\
(0.091)\end{array}$ & $\begin{array}{c}-0.0294 \\
(0.11)\end{array}$ & $\begin{array}{l}-0.00747 \\
(0.11)\end{array}$ & $\begin{array}{l}-0.00747 \\
(0.11)\end{array}$ \\
\hline Infrastructure (Year 1) & $\begin{array}{l}0.495^{\star} \\
(0.15)\end{array}$ & $\begin{array}{r}0.156 \\
(0.16)\end{array}$ & $\begin{array}{l}0.448^{*} \\
(0.14)\end{array}$ & $\begin{array}{l}0.413^{*} \\
(0.16)\end{array}$ & $\begin{array}{l}0.475^{\star} \\
(0.20)\end{array}$ & $\begin{array}{r}0.129 \\
(0.21)\end{array}$ & $\begin{array}{r}0.129 \\
(0.21)\end{array}$ \\
\hline $\begin{array}{l}\text { Years Since Party } \\
\text { Congress }\end{array}$ & & & $\begin{array}{c}0.182 \\
(0.042)\end{array}$ & $\begin{array}{r}0.181^{\star} \\
(0.042)\end{array}$ & $\begin{array}{c}0.150^{*} \\
(0.048)\end{array}$ & $\begin{array}{r}0.143^{\star} \\
(0.049)\end{array}$ & $\begin{array}{c}0.143^{*} \\
(0.049)\end{array}$ \\
\hline City Dummy & & $\begin{array}{r}0.151 \\
(0.37)\end{array}$ & & $\begin{array}{r}0.183 \\
(0.43)\end{array}$ & $\begin{array}{r}0.161 \\
(0.48)\end{array}$ & $\begin{array}{r}-0.165 \\
(0.47)\end{array}$ & $\begin{array}{r}-0.165 \\
(0.47)\end{array}$ \\
\hline Southern Dummy & & $\begin{array}{r}-0.213 \\
(0.14)\end{array}$ & & $\begin{array}{l}0.0109 \\
(0.14)\end{array}$ & $\begin{array}{l}0.0549 \\
(0.16)\end{array}$ & $\begin{array}{c}-0.204 \\
(0.17)\end{array}$ & $\begin{array}{c}-0.204 \\
(0.17)\end{array}$ \\
\hline $\begin{array}{l}\text { Net Autonomy of } \\
\text { region }(\mathrm{fd})\end{array}$ & & & & & $\begin{array}{l}0.0708 \\
(0.16)\end{array}$ & $\begin{array}{l}0.0588 \\
(0.16)\end{array}$ & $\begin{array}{l}0.0588 \\
(0.16)\end{array}$ \\
\hline $\begin{array}{l}\text { Natural Log of GDP } \\
\text { per Capita (fd) }\end{array}$ & & $0.753^{\star}$ & & & & $\begin{array}{l}0.934^{*} \\
(0.24)\end{array}$ & $\begin{array}{l}0.934^{*} \\
(0.24)\end{array}$ \\
\hline Constant & $\begin{array}{c}-0.0830 \\
(0.16)\end{array}$ & $\begin{array}{l}-0.700^{* * *} \\
(0.19)\end{array}$ & $\begin{array}{c}-0.457^{\star} \\
(0.17)\end{array}$ & $\begin{array}{c}-0.481^{\star} \\
(0.21)\end{array}$ & $\begin{array}{c}-0.271 \\
(0.26)\end{array}$ & $\begin{array}{c}-1.095^{\star} \\
(0.33)\end{array}$ & $\begin{array}{c}-1.095^{\star} \\
(0.33)\end{array}$ \\
\hline Observations & 503 & 503 & 503 & 503 & 503 & 503 & 425 \\
\hline Wald Chi2 & 29.2 & 41.57 & 42.11 & 41.95 & 41.95 & 31.81 & 45.86 \\
\hline
\end{tabular}

All models assume panel-specific AR1 processes and panel-level heteroskedatic errors (Standard errors in parentheses)

${ }^{\star}$ Indicates significance at the .05 level (two-tailed test).

(lag1) lagged 1 year; (fd): indicates the first difference of variable taken.

$\dagger$ Naïve regression indicates regression that does not address endogeneity.

$\ddagger$ Restricted model includes only variables also used in equation 1 - the determinants of FDI/GDP.

$\psi$ First stage of two-stage simultaneous equation model.

an effect on net flows of foreign investment that is significantly different from zero. The negative sign on cases of autonomy is the opposite of the prediction that investors would be attracted to these reforms. Clearly, structural conditions such as distance from markets, the structure of the economy (agriculture output/GDP), population size, and initial infrastructure (significant at the 0.10 level), have a far more robust impact on attracting investors. This confirms anecdotal evidence about the needs of Vietnam's early investors from the Asian region. The impact of these variables becomes weaker once the lagged dependent variable is added, but this is because previous investors were also influenced by structural conditions in addition to agglomeration. The Asian Financial Crisis dummy has the predicted sign on the coefficient, but is only statistically significant in the final model. Secondary School is strongly related to FDI in the predicted, negative direction.

The second equation, however, shows clearly that FDI has a positive and significant impact on autonomy in every specification, persuasively confirming the hypothesis of FDI and de facto decentralization. In the most fully specified equation not including lagged FDI (Model 4), the overall probability of autonomous action is about $42 \%$ with all variables set to the their mean. Increasing the stock of FDI from the $50^{\text {th }}$ percentile $\left(2.6 \%\right.$ of GDP) to the $75^{\text {th }}$ percentile (14.5\% of GDP) on the other hand raises the probability of autonomous action by about $9.8 \%$. Figure 3 extends the analysis of the probability of autonomy. Holding all other variables at their mean value, it allows the stock of FDI as a percentage of GDP to vary from the $1^{\text {st }}$ percentile $(0 \%)$ to the $90^{\text {th }}$ 


\section{TABLE 4. Simultaneous Equation Model - Equation 1 (Model of Foreign Direct Investment/GDP with Panel Corrected Standard Errors)}

\begin{tabular}{|c|c|c|c|c|c|}
\hline $\begin{array}{l}\text { Dependent Variable }= \\
\text { Stock of FDI / GDP }(\mathbf{f d}) \\
\text { (Continuous Variable) }\end{array}$ & $\begin{array}{l}\text { Baseline }^{\psi} \\
\text { (1) }\end{array}$ & $\begin{array}{c}\text { Geo Dummies } \\
(2)\end{array}$ & $\begin{array}{l}\text { Diffusion }^{\psi} \\
\text { (3) }\end{array}$ & $\begin{array}{c}\text { Size of } \\
\text { Economy } \\
(4)\end{array}$ & $\begin{array}{c}\text { Lagged } \\
\text { Dependant } \\
\quad(5)\end{array}$ \\
\hline Case of Fence-Breaking $\dagger$ & $\begin{array}{r}-1.451 \\
(1.18)\end{array}$ & $\begin{array}{r}-1.553 \\
(1.12)\end{array}$ & $\begin{array}{c}-2.278 \\
(1.23)\end{array}$ & $\begin{array}{r}-2.405 \\
(1.28)\end{array}$ & $\begin{array}{r}-1.659 \\
(1.03)\end{array}$ \\
\hline $\begin{array}{l}\% \text { of secondary school } \\
\text { graduates }(\mathrm{fd})\end{array}$ & $\begin{array}{c}-0.0894^{\star} \\
(0.029)\end{array}$ & $\begin{array}{c}-0.0886^{\star} \\
(0.028)\end{array}$ & $\begin{array}{c}-0.0746^{*} \\
(0.030)\end{array}$ & $\begin{array}{c}-0.0761^{\star} \\
(0.030)\end{array}$ & $\begin{array}{c}-0.0885^{\star} \\
(0.028)\end{array}$ \\
\hline $\begin{array}{l}\text { Distance from major } \\
\text { market }\end{array}$ & $\begin{array}{c}-0.00539^{*} \\
(0.0018)\end{array}$ & $\begin{array}{l}-0.00520^{*} \\
(0.0019)\end{array}$ & $\begin{array}{r}-0.00621 \\
(0.0025)\end{array}$ & $\begin{array}{c}-0.00434^{*} \\
(0.0020)\end{array}$ & $\begin{array}{c}-0.00233 \\
(0.0016)\end{array}$ \\
\hline $\begin{array}{l}\text { Population in } 10000 \text { s } \\
\text { (fd) }\end{array}$ & $\begin{array}{l}0.269^{*} \\
(0.12)\end{array}$ & $\begin{array}{c}(0.0019) \\
0.189^{\star}\end{array}$ & $\begin{array}{c}(0.0025) \\
0.223^{\star}\end{array}$ & $\begin{array}{r}(0.0020) \\
0.249^{* *}\end{array}$ & $\begin{array}{c}(0.0016) \\
0.182^{\star}\end{array}$ \\
\hline $\begin{array}{l}\text { Agriculture Output/GDP } \\
\text { (fd) }\end{array}$ & $\begin{array}{c}-0.0455^{\star} \\
(0.016)\end{array}$ & $\begin{array}{c}-0.0451^{\star} \\
(0.016)\end{array}$ & $\begin{array}{l}-0.0545^{\star} \\
(0.017)\end{array}$ & $\begin{array}{c}-0.0586^{\star} \\
(0.018)\end{array}$ & $\begin{array}{c}-0.0330^{\star} \\
(0.015)\end{array}$ \\
\hline Infrastructure (Year 1) & $\begin{array}{l}3.458^{*} \\
(1.06)\end{array}$ & $\begin{array}{c}1.856 \\
(1.01)\end{array}$ & $\begin{array}{r}2.322 \\
(1.21)\end{array}$ & $\begin{array}{c}1.508 \\
(1.09)\end{array}$ & $\begin{array}{r}0.657 \\
(1.19)\end{array}$ \\
\hline $\begin{array}{l}\text { Years of Asian Financial } \\
\text { Crisis }\end{array}$ & $\begin{array}{r}-0.341 \\
(0.82)\end{array}$ & $\begin{array}{r}-0.225 \\
(0.81)\end{array}$ & $\begin{array}{r}-1.167 \\
(0.88)\end{array}$ & $\begin{array}{c}-1.414 \\
(0.91)\end{array}$ & $\begin{array}{c}-1.711^{\star} \\
(0.85)\end{array}$ \\
\hline City Dummy & & $\begin{array}{r}5.702 \\
(3.40)\end{array}$ & $\begin{array}{r}6.021 \\
(3.77)\end{array}$ & $\begin{array}{r}5.469 \\
(3.77)\end{array}$ & $\begin{array}{r}2.966 \\
(3.88)\end{array}$ \\
\hline Southern Dummy & & $\begin{array}{r}1.223 \\
(0.65)\end{array}$ & $\begin{array}{l}1.533^{*} \\
(0.77)\end{array}$ & $\begin{array}{r}0.624 \\
(0.79)\end{array}$ & $\begin{array}{r}0.609 \\
(0.69)\end{array}$ \\
\hline $\begin{array}{l}\text { Natural Log of GDP per } \\
\text { Capita (fd) }\end{array}$ & & & & $\begin{array}{r}2.289 \\
(1.41)\end{array}$ & $\begin{array}{r}0.713 \\
(1.06)\end{array}$ \\
\hline $\begin{array}{l}\text { Stock FDI/GDP (fd) } \\
\quad(\operatorname{lag} 1)\end{array}$ & & & & & $\begin{array}{l}0.515^{*} \\
(0.12)\end{array}$ \\
\hline Constant & $\begin{array}{l}4.623^{\star} \\
(0.89)\end{array}$ & $\begin{array}{l}2.974^{\star} \\
(0.76)\end{array}$ & $\begin{array}{l}3.502^{*} \\
(0.91)\end{array}$ & $\begin{array}{l}1.324 \\
(1.37)\end{array}$ & $\begin{array}{r}0.639 \\
(1.33)\end{array}$ \\
\hline Observations & 503 & 503 & 425 & 425 & 425 \\
\hline R-Squared & 0.10 & 0.11 & 0.13 & 0.13 & 0.30 \\
\hline
\end{tabular}

All models assume panel-specific AR1 processes and panel-level heteroskedatic errors (Standard errors in parentheses)

${ }^{\star}$ Indicates significance at the .05 level (two-tailed test).

(lag1) lagged 1 year; (fd): indicates the first difference of variable taken.

$\dagger$ Instrument for Case of Autonomy Derived from Simultaneous Model in Equation 2.

$\psi$ Second stage of two-stage simultaneous equation model.

percentile (204\% of GDP). By doing this, it is possible to see that FDI has a non-linear effect on the probability of autonomous actions. The probability of autonomy changes very little and in fact is even slightly negative at very low levels until it crosses a tipping point at about the $60^{\text {th }}$ percentile $(5.3 \%$ of GDP). Once that threshold is crossed, the probability of fence breaking shoots up rapidly, approaching $70 \%$ when the very top provinces are reached. This confirms the theory that changes in stocks of FDI can act as a spur to provincial reform among lucky recipients. The steady upward slope beginning at the $60^{\text {th }}$ percentile indicates that while the likelihood of fence breaking is highest in the very top FDI-recipient provinces, the relationship is not driven by them. This has been confirmed by diagnostics measuring the influence of the two outliers (Hanoi in one case and
HCMC in three cases) and a battery of regressions dropping them with little impact on coefficients. ${ }^{15}$

A number of political control variables are statistically significant and are therefore worth exploring in more detail. Provinces are strategic about the timing of fence breaking, preferring to act autonomously in political periods that are less likely to demand immediate political responses by central-level officials, such as in the run-up or immediate aftermath of a Party Congress. Statistically, provinces are 33\% more likely to experiment in year 4 than in year 1. Evidence also seems to indicate that powerful compatriots in the

\footnotetext{
${ }^{15}$ Please observe the leverage-versus-residual plot in online Appendix 6, which charts the influence of outliers on the regression (Column 2). The results indicate four outliers, but online Appendix 7 shows that dropping these outliers has little impact on results.
} 
TABle 5. Simultaneous Equation Model - Equation 2 (Probit Model of Fence-breaking with Standard Errors Clustered at Panel Level)

\begin{tabular}{|c|c|c|c|c|c|}
\hline $\begin{array}{l}\text { Dependent Variable }= \\
\text { Case of Fence-Breaking } \\
\text { (Dichotomous Variable) }\end{array}$ & $\begin{array}{l}\text { Baseline }^{\psi} \\
\text { (1) }\end{array}$ & $\begin{array}{c}\text { Geo Dummies }{ }^{\psi} \\
(2)\end{array}$ & $\begin{array}{c}\text { Diffusion }^{\psi} \\
(3)\end{array}$ & $\begin{array}{c}\text { Size of } \\
\text { Economy } \\
(4)\end{array}$ & $\begin{array}{c}\text { Lagged } \\
\text { Dependant } \\
\quad(5) \\
\end{array}$ \\
\hline Stock of FDI/GDP $(\mathrm{fd})^{\dagger}$ & $\begin{array}{c}0.141^{*} \\
(0.049)\end{array}$ & $\begin{array}{r}0.152^{*} \\
(0.053)\end{array}$ & $\begin{array}{c}0.183^{\star} \\
(0.062)\end{array}$ & $\begin{array}{r}0.147^{\star} \\
(0.063)\end{array}$ & $\begin{array}{l}0.0666^{\star} \\
(0.022)\end{array}$ \\
\hline $\begin{array}{l}\text { Years Since Party } \\
\text { Congress }\end{array}$ & $\begin{array}{r}0.259^{*} \\
(0.053)\end{array}$ & $\begin{array}{r}0.267^{\star} \\
(0.055)\end{array}$ & $\begin{array}{c}0.324^{\star} \\
(0.076)\end{array}$ & $\begin{array}{r}0.285^{\star} \\
(0.078)\end{array}$ & $\begin{array}{r}0.207^{*} \\
(0.053)\end{array}$ \\
\hline $\begin{array}{l}\text { Province the Result of } \\
\text { Separation }\end{array}$ & $\begin{array}{r}-0.265 \\
(0.14)\end{array}$ & $\begin{array}{c}-0.327^{\star} \\
(0.14)\end{array}$ & $\begin{array}{c}-0.367^{\star} \\
(0.15)\end{array}$ & $\begin{array}{r}-0.276 \\
(0.15)\end{array}$ & $\begin{array}{r}-0.260 \\
(0.14)\end{array}$ \\
\hline $\begin{array}{l}\text { Number of Compatriots } \\
\text { in Cabinet }\end{array}$ & $\begin{array}{c}0.128 \\
(0.067)\end{array}$ & $\begin{array}{c}0.125 \\
(0.069)\end{array}$ & $\begin{array}{c}0.173^{\star} \\
(0.077)\end{array}$ & $\begin{array}{r}0.183^{*} \\
(0.077)\end{array}$ & $\begin{array}{c}0.170^{*} \\
(0.074)\end{array}$ \\
\hline $\begin{array}{l}\text { Party Control of } \\
\text { Provincial Leader }\end{array}$ & $\begin{array}{r}-0.0612 \\
(0.099)\end{array}$ & $\begin{array}{l}-0.00117 \\
(0.096)\end{array}$ & $\begin{array}{c}-0.0649 \\
(0.11)\end{array}$ & $\begin{array}{c}-0.0412 \\
(0.11)\end{array}$ & $\begin{array}{c}-0.0154 \\
(0.11)\end{array}$ \\
\hline Infrastructure (Year 1) & $\begin{array}{r}0.186 \\
(0.19)\end{array}$ & $\begin{array}{l}0.373^{*} \\
(0.18)\end{array}$ & $\begin{array}{r}0.310 \\
(0.20)\end{array}$ & $\begin{array}{l}0.0431 \\
(0.21)\end{array}$ & $\begin{array}{l}0.0995 \\
(0.20)\end{array}$ \\
\hline City Dummy & & $\begin{array}{r}-0.912 \\
(0.56)\end{array}$ & $\begin{array}{r}-1.102 \\
(0.62)\end{array}$ & $\begin{array}{r}-1.136 \\
(0.62)\end{array}$ & $\begin{array}{r}-0.588 \\
(0.47)\end{array}$ \\
\hline Southern Dummy & & $\begin{array}{r}-0.137 \\
(0.15)\end{array}$ & $\begin{array}{r}-0.105 \\
(0.17)\end{array}$ & $\begin{array}{r}-0.297 \\
(0.17)\end{array}$ & $\begin{array}{r}-0.247 \\
(0.16)\end{array}$ \\
\hline $\begin{array}{l}\text { Net Autonomy of } \\
\text { region }(\mathrm{fd})\end{array}$ & & & $\begin{array}{l}0.442^{\star} \\
(0.21)\end{array}$ & $\begin{array}{c}0.363 \\
(0.21)\end{array}$ & $\begin{array}{r}0.110 \\
(0.17)\end{array}$ \\
\hline $\begin{array}{l}\text { Natural Log of GDP } \\
\text { per Capita (fd) }\end{array}$ & & & & $\begin{array}{l}0.812^{*} \\
(0.24)\end{array}$ & $\begin{array}{l}0.838^{*} \\
(0.22)\end{array}$ \\
\hline Constant & $\begin{array}{c}-0.979^{*} \\
(0.28)\end{array}$ & $\begin{array}{c}-0.836^{*} \\
(0.28)\end{array}$ & $\begin{array}{c}-1.040^{\star} \\
(0.37)\end{array}$ & $\begin{array}{c}-1.609^{*} \\
(0.39)\end{array}$ & $\begin{array}{c}-1.298^{*} \\
(0.32)\end{array}$ \\
\hline Observations & 503 & 503 & 416 & 416 & 416 \\
\hline Wald Chi2 & 44.87 & 45.17 & 40.25 & 51.16 & 59.05 \\
\hline
\end{tabular}

All models assume panel-specific AR1 processes and panel-level heteroskedatic errors (Standard errors in parentheses).

${ }^{\star}$ Indicates significance at the .05 level (two-tailed test).

(lag1) lagged 1 year; (fd): indicates the first difference of variable taken.

$\dagger$ Instrument for Case of Autonomy Derived from Simultaneous Model in Equation 1.

$\psi$ Second stage of two-stage simultaneous equation model.

cabinet (most likely reformers) may protect provincial leaders from punishment, as they engage in experimentation. One provincial compatriot serving in the cabinet increases the probability of autonomy by $7.1 \%$ from zero cabinet members; a second cabinet member increases autonomy by an additional $7.2 \%$. Finally, previously separated provinces are $11 \%$ less likely than provinces which have maintained their original boundaries to engage in fence-breaking activity, indicating that the local-central clientelistic relationships which led to their creation restricts the new leaders' ability to act autonomously. Party Control has no impact on provincial autonomy in Vietnam and is not highly correlated with the number of cabinet officials, so multicollinearity must be eliminated as a source of the variable's insignificance.

Provinces do appear to be learning from their neighbors, as shown by Models 4 and 5. A one standard deviation shift in the net fence-breaking activities of a province's regional neighbors increases the probability of a fence-breaking experiment by about $14 \%$. The most influential factor is changes in the GDP per capita of the province. A one standard deviation shift in GDP per capita would yield a 31\% increase in the probability of autonomy. Other well-known factors do not have robust effects on fence breaking; southern proximity, whether the province is a metropolis, and initial infrastructure are not significantly different from 0 in most models. Controlling for all of these political and structural mechanisms, however, FDI continues to remain influential in every model.

Because of the dominance of export-oriented investors in Vietnam, it is possible that exports and not FDI drive results. Due to data limitations, this is hard to test convincingly. As a result, it is not included in the body of the paper. Appendix 7 (Column 1), however, shows the result of the second equation when controlling for exports as a percentage of GDP. In this 
FIgURE 3.

\section{Predicted Probabilities of Simultaneous Equation 2} The Impact of FDI on Provincial Autonomy

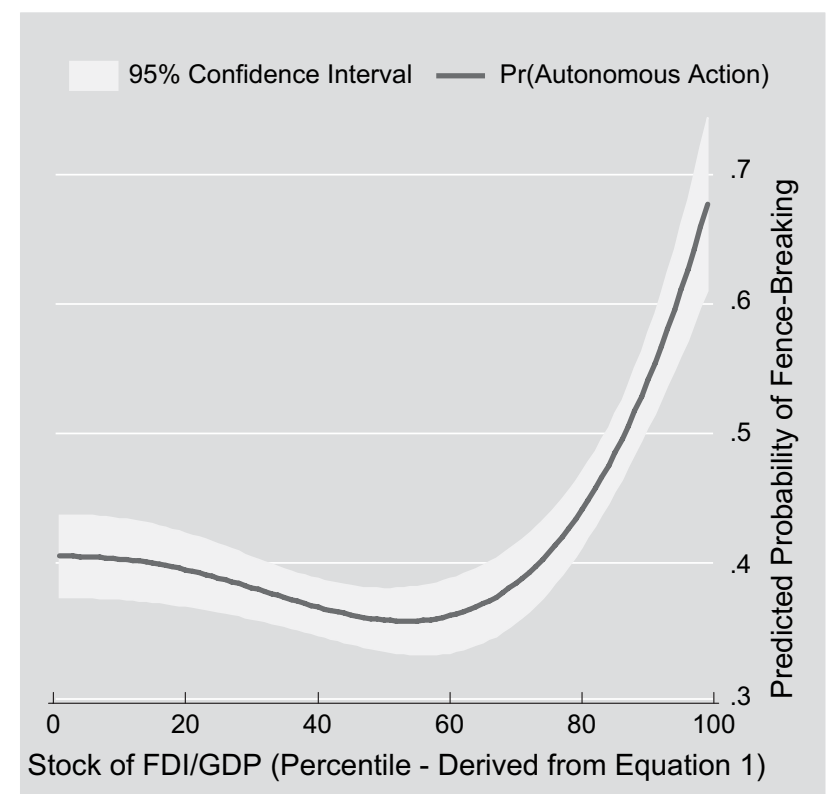

model, FDI remains significant with only a marginal change in the size of its coefficient. Moreover, exports have no independent effect on cases of fence breaking. Results should be treated with some caution, but it does provide some verification that FDI is the primary source of de facto decentralization, not exports.

\section{Conclusion}

The hypotheses of Jones-Luong (2002) and Zweig (2003) have been upheld in this direct test. FDI appears to have a powerful and robust impact on de facto decentralization regarding economic policy. These findings are an important corrective to the present literature on FDI, which has tended to concentrate too heavily on political factors that attract investment, while neglecting the role investors have in altering domestic institutions and policy. In fact, this analysis reveals that foreign investors in Vietnam have been far more attracted to more structural determinants, such as distance from major markets, population size, and the preexisting composition of the economy, than they have provincial policy experiments. Once committed to a locale, however, foreign investors simultaneously provide an incentive and the bargaining power for provincial leaders to pursue initiatives outside of central law.
This article has also detailed the microprocesses of de facto decentralization without resort to myopia or irrationality. While central officials were generally opposed to local economic policy experiments and their two implications-surrender of policy authority and injury to the state-owned sector-their reliance on the revenue generated by FDI-attractors prevented central officials from taking vigorous action to reignin illegal behavior. Instead they relied on signaling through the state-owned press, which deterred weaker provinces from following suit, but had little impact on those driving the reform initiatives. Moreover, it appears that some central officials, who were sympathetic to the reform attempts, may have even shielded such activities, a speculation borne out by the fact that provinces with compatriots working in the cabinet were more likely than unprotected provinces to engage in autonomous experiments.

This article has contributed the initial stage for an expansive research agenda. It has offered a micrologic and confirmed one theoretical mechanism for de facto decentralization through thorough empirical testing. Space constraints, however, prevent further exploration into the complexities of these findings. Future publications will drill deeper to sort out new questions arising from this analysis. First, this paper bracketed the role played by investors in lobbying and agitating for provincial experiments which would benefit their businesses. Future work will lay out the microprocesses through which investors alter the provincial policy environments in developing countries. Second, FDI in Vietnam is heavily dominated by exportoriented industries. There is reason to believe investment geared toward domestic sales or natural resource exploitation may have differential impacts in other countries, requiring a conditional hypothesis. In generalizing from Vietnam to other contexts, it is necessary to keep in mind the unique dominance of exportoriented investors in the country. Countries dominated by domestic-oriented FDI may not see the same impact on de facto decentralization. Finally, many provincial policy reforms in Vietnam were eventually adopted into national-level legislation. It is important to understand how this occurred and what role provincial representatives played in the process.

\section{Acknowledgments}

Special thanks are due to the National Security Education Project for field research funding, the Institute of World Economy for hosting my stay in Hanoi, Vietnam, and Lily Phan, Nguyen Hung and 
Nguyen Thi Oanh for valuable research assistance. Robert Keohane, Herbert Kitschelt, David Dapice, Karen Remmer, David Soskice, Timothy Frye, Daniel Treisman, Helen Milner, Lisa Martin, Martin Gainsborough, and three anonymous reviewers provided helpful comments and advice.

\section{Manuscript submitted 20 September 2006 \\ Manuscript accepted for publication 8 March 2007}

\section{References}

Abrami, Regina M. 2003. "By Rule, Reason or Ritual? Political Norms and the Making of Vietnam's 'Non-State' in State Socialism." Presented at International Conference on Asian Studies, Singapore.

Abrami, Regina M. 2004. "Bottlenecks, Beliefs, and Breakthroughs: The Normative Logic of Economic Reform in Vietnam." Harvard Business School Working Paper Series 05-007. Harvard University.

Alesina, Alberto, Enrico Spolaore, and Romain Wacziarg. 2000. "Economic Integration and Political Disintegration." American Economic Review, 90 (5): 1276-96.

Alvarez R. Michael, and Garret Glasgow. 2000. "Two-Stage Estimation of Non-Recursive Choice Models." Political Analysis, 8 (2): 147-65.

Anh, Le Viet. 2004. "Locational Determinants of Foreign Direct Investment." Presented at Japanese-Vietnam Economic Cooperation Meeting, Hanoi.

Asia Times, "Vietnam Trading on More Investment" Special Reports. September 9, 2000. www.atimes.com/reports/BI09.Ai05. html (December 7, 2006)

Beck, Nathaniel, and Jonathan Katz. 1995. "What to do (and Not to Do) with Time-Series Cross-Section Data." AmericanPolitical Science Review 89 (3): 634-48.

Binh Duong Statistical Office. 2001. Statistical Handbook. Binh Duong, Vietnam.

Bird, Richard M., Jennie I. Litvak, and M. Govinda Rao. 1995. "Intergovernmental Fiscal Relations and Poverty Alleviation in Viet Nam." World Bank Policy Research Working Paper 1430, March.

Bolton, Kent. 1999. "Domestic Sources of Vietnam's Foreign Policy." In Vietnamese Foreign Policy in Transition, ed. Caryle Thayer and Rames Amer. New York: St. Martin's Press, 170-201.

Bolton, Patrick, and Gerard Roland. 1997. "The Breakup of Nations: A Political Economy Analysis." The Quarterly Journal of Economics 112 (4): 1057-90.

Blanton, Shannon L., and Robert G. Blanton. 2007. "What Attracts Foreign Investors? An Examination of Human Rights and Foreign Direct Investment.” Journal of Politics 69 (1): 1-35.

Diaz-Cayero, Alberto, Beatriz Magaloni, and Barry R. Weingast. 2003. "Tragic Brilliance: Equilibrium Hegemony and Democratization in Mexico." Working Paper, Hoover Institution, Stanford University.

Dung, Nguyen Chi. 2001. "Local Governments in Vietnam.”Nghien Cuu Lap Phap [Legislative Studies Magazine], August.

Echeverri-Gent, John. 2000. "Globalization and Decentralization: Lessons for Good Governance from China and India."
Presented for the Yale University Colloquium on Decentralization and Development.

Engle, Robert F., and Clive W. J. Granger. 1987. "Co-Integration and Error-Correction: Representation, Estimation and Testing." Econometrica 55 (2): 251-76.

Fforde, Adam. 1989. "Major Economic Changes and SocioEconomic Development in Vietnam since Mid-1988." In Doi Moi: Economic Reforms and Development Policies in Vietnam, ed. Per Ronnas and O. Sjoberg. Hanoi: Swedish International Development Agency and the Central Institute for Economic Management, 14-18.

Fforde, Adam. 2002. "Light within the ASEAN Gloom? The Vietnamese Economy Since the First Asian Economic Crisis (1997) and in the Light of the 2001 Downturn." In Southeast Asian Affairs, ed. Dalight Sing and Anthony L. Smith. Singapore: Institute of Southeast Asian Studies, 357-77.

Fforde Adam. 2005. "Vietnam's Successful Turnaround and the Intentionality Issue." Presented at World Bank, Hanoi.

Fforde, Adam, and Stefan de Vylder. 1996. From Plan to Market: The Economic Transition in Vietnam. Boulder: Westview Press.

Foreign Institute Advisory Service (FIAS). 1999. Vietnam Attracting More and Better Foreign Direct Investment. Washington: World Bank.

Freeman, Nick, and Curt Nestor. 2004. "Rethinking Foreign Investment in Vietnam: Fuzzy Figures and Sentiment Swings." In Rethinking Vietnam, ed. Duncan McCargo, London: RoutledgeCurzon, 179-96.

Fritzen, Scott. 2002. "The 'Foundation of Public Administration'? Decentralization and Its Discontents in Transitional Vietnam." Public Policy Program Working Paper Series 23, National University of Singapore.

Fung, K.C., Hitoma Iizaka, Chelsea Lin, and Alan Siu. 2002. “An Econometric Estimation of Locational Choices of Foreign Direct Investment: The Case of Hong Kong and U.S. Firms in China." Center for International Economics Working Paper. University of California, Santa Cruz.

Gainsborough, Martin. 2001. "The Centre Strikes Back: Big Corruption Cases and the Politics of Economic Decentralization in Vietnam." Presented at Euroseas Conference, London.

Gainsborough, Martin. 2003. The Changing Political Economy of Vietnam. New York: RoutledgeCurzon.

Gainsborough, Martin. 2004. “Ho Chi Minh City's Post-1975 Political Elite: Continuity and Change in Background and Belief." In Beyond Hanoi: Local Government in Vietnam, ed. Ben Kerkvliet and David Marr. Singapore: Institute of Southeast Asian Studies, 259-84.

Gallagher, Mary. 2002. "Reform and Openness: Why China's Economic Reforms Have Delayed Democracy." World Politics 54 (3): 338-72.

General Statistical Office (GSO). 1995-2006 (various years). Statistical Handbook. Hanoi, Vietnam: Statistical Publishing House.

Gourevitch, Peter Alexis. 1979. “The Reemergence of 'Peripheral Nationalisms': Some Comparative Speculations on the Spatial Distribution of Political Leadership and Economic Growth." Comparative Studies in Society and History 21 (3): 303-57.

Government of Vietnam. 1992. 1992 Constitution. Hanoi: The Gioi Publishers.

Government of Vietnam-Donor Working Group (GVDWG). 2000. Vietnam Managing Public Resources Better: Public Expenditure Review. Hanoi: World Bank. 
Granger, Clive, and Pauk Newbold. 1974. "Spurious Regression in Econometrics." Journal of Econometrics 2: 111-20.

Hadri, Kaddour. 2000. "Testing for Stationarity in Heterogeneous Panel Data." The Econometrics Journal 3: 148-61.

Ha Tinh Statistical Office. 2001. Statistical Handbook. Ha Tinh, Vietnam.

Hellman, Joel. 1998. "Winners Take All: The Politics of Partial Reform in Post-Communist Transitions." World Politics 50 (2): 203-34.

Helpman, Elhanan. 2004. The Mystery of Economic Growth. Cambridge: Harvard University Press.

Helmke, Gretchen, and Stephen Levitsky. 2005. "Informal Institutions and Comparative Politics: A Research Agenda." Perspectives on Politics 2 (4): 725-40.

Henisz, Witold, J. 2000. "The Institutional Environment for Multinational Investment." Journal of Law, Economics, and Organization 16 (2): 334-64.

Henisz, Witold J., and Andrew Delios. 2004. "Information or Influence? The Benefits of Experience for Managing Political Uncertainty." Strategic Organization 2 (4): 389-421.

Herrera, Yoshiko. 2005. Imagined Economies: The Sources of Russian Regionalism. Cambridge: Cambridge University Press.

Hiscox, Michael. 2000. "Political Integration and Disintegration in the Global Economy." In Governance in a Global Economy: Political Authority in Transition, ed. Miles Kahler and David Lake. Princeton: Princeton University Press, 60-86.

Huang, Yasheng. 1996. Inflation and Investment Controls in China: The Political Economy of Central-Local Relations during the Reform Era. Cambridge: Cambridge University Press.

Hutchcroft, Paul D. 2001. "Centralization and Decentralization in Administration and Politics: Assessing Territorial Dimensions of Authority and Power." Governance: An International Journal of Policy and Administration 14 (1): 25-53.

Japan Bank for International Cooperation (JBIC). 2005. "Survey Report on Overseas Business Operations by Japanese Manufacturing Companies: Results of JBIC FY 2004 Survey: Outlook for Japanese Foreign Direct Investment (16th Annual Survey)." JBICI Review 13: 1-94.

Jia Hao, and Lin Zhimin, eds. 1994. Changing Central-Local Relations in China: Reform and State Capacity. Boulder: Westview Press.

Jensen, Nathan M. 2003. "Democratic Governance and Multinational Corporations: Political Regimes and Inflows of Foreign Direct Investment." International Organization 57 (Summer): 587-616.

Jensen, Nathan. 2006. Nation-States and the Multinational Corporation: A Political Economy of Foreign Direct Investment. Princeton: Princeton University Press.

Jones-Luong, Pauline. 2003. "Economic Decentralization in Kazakhstan: Causes and Consequences." In The Transformation of Central Asia: States and Societies from Soviet Rule to Independence, ed. Jones-Luong. Ithaca: Cornell University Press, 182-212.

Kennedy, Peter. 1993. A Guide to Econometrics. Cambridge: MIT Press.

Kerkvliet, Benedict J. Tria. 2001. "An Approach for Analyzing State-Society Relations in Vietnam." Sojourns 16 (2): 238-78.

Keshk, Omar M.G. 2003. "CDSIMEQ: A program to Implement Two-Stage Probit Least Squares." Stata Journal 3 (2): 157-67.

King, Gary, Robert O. Keohane, and Sidney Verba. 1994. Designing Social Inquiry: Scientific Inference in Qualitative Research. Princeton: Princeton University Press.
Kobrin, Stephen J. 1987. "Testing the Bargaining Hypothesis in the Manufacturing Sector in Developing Countries." International Organization 4 (Fall): 609-38G.

Kokko, Ari, Katarina Kotoglu, and Anna Krohwinkel-Karlsson. 2003. "The Implementation of FDI in Vietnam and Analysis of the Characteristics of Failed Projects." Transnational Corporations 12 (3): 40-77.

Kopstein, Jeffrey, and David Reilly. 2000. "Geographic Diffusion and the Transformation of the Post-Communist World." World Politics 53 (October): 1-37.

Krugman, Paul. 1993. Geography and Trade. Cambridge: MIT Press.

Ky, Bui Van. 1996. "May van de ve xay dung va bao ve to quoc XHCN tron boi canh the gioi hien nay." [ A few problems with constructing and defending national socialist orientation in the context of the modern world]. Tap Chi Cong San [Communist Review] 16.

Lam, Willy Wo-Lap. 1999. The Era of Jiang Zemin. Singapore: Prentice Hall.

Landry, Pierre F. 2002. "Performance, Markets, and the Political Fate of the Chinese Mayors." Presented at the annual meeting of the American Political Science Association, Boston.

Landry, Pierre F. 2004. Do Informal Networks Subvert Formal Institutions? Presented at Conference on Globalization and Self-Determination: The Nation-State under Siege, Yale University.

Li, Quan, and Adam Resnick. 2002. "Reversal of Fortunes: Democratic Institutions and Foreign Direct Investment Inflows to Developing Countries." International Organization 57 (1): 175-211.

Lao Dong. 1993. "Bai hoc tra gia qua dat can xu ly nghiem khac sai pham tai tinh Ba Ria Vung Tau." [Settlement of the illegal land use activities of BRVT]. Lao Dong [Labor], December 2.

Maddala, G.S. 1983. Limited-Dependent and Qualitative Variables in Econometrics. Cambridge: Cambridge University Press.

Mai, Pham Hoan. 1998. FDI and Development in Vietnam. Singapore: Institute for Southeast Asian Studies.

Malesky, Edmund. 2004. "Leveled Mountains and Broken Fences: Measuring and Analyzing De Facto Decentralization in Vietnam." European Journal of South East Asian Studies 3 (2): 307-37.

Malesky, Edmund. 2006. "Gerrymandering Vietnamese Style: The Political Motivations behind the Creation of New Provinces in Vietnam." Presented at the Democracy, Governance, and Identity Conference, International Institute of the University of Michigan.

Markusen, Thomas. 1998. "Multinational Firms, Location and Trade," World Economy 21 (6): 733-56.

Masina, Pietro. 2002. "Vietnam and the Regional Crisis: The Case of a 'Late-Comer'." European Journal of East Asian Studies 1 (2): 177-220.

Mason, Mark. 1998. "Foreign Direct Investment in Vietnam: Government Policies and Corporate Strategies" EXIM Review 17 (2): 1-70.

Meyer, Klaus E., and C. Pind. 1999. "The Slow Growth of Foreign Direct Investment in the Soviet Successor States." Economics of Transition, 7 (1): 135-50.

Meyer, Klaus E., and Hung Vo Nguyen. 2005. "Foreign Investment Strategies and Subnational Institutions in Emerging Markets: Evidence from Vietnam." Journal of Management Studies 42 (1): 63-93.

Mitchneck, Beth. 1995. "An Assessment of the Growing Local Economic Development of Local Authorities in Russia" Economic Geography 71 (2): 150-70. 
Ministry of Finance (MOF) of Vietnam. 1997-2005 (Various Years). State Budget. Hanoi: Financial Publishing House. Detailed data available at www.mof.gov.vn (December 8, 2006).

Montinola, Gabriella, Yingyi Qian, and Barry Weingast. 1995. "Federalism Chinese Style: The Political Basis for Economic Success in China." World Politics 48 (1): 50-81.

Naughton, Barry. 1995. Growing Out of the Plan. Cambridge: Cambridge University Press.

Nien Giam To Chuc Hanh Chinh Vietnam (NGTCHCV). 19982004 (Various Years). [Compendium of Administration in Vietnam], Hanoi: Nha Xuat Ban Thong Ke [Statistical Publishing House].

Orttung, Robert. 2004. "The Impact of New Business Actors on the Emergence of the Rule of Law in Russian Regions." Presented at annual meeting of the American Political Science Association, Chicago.

Porter, Gareth. 1993. Vietnam: The Politics of Bureaucratic Socialism. Ithaca: Cornell University Press.

Pye, Lucian W. 1991. "The State and the Individual: An Overview Interpretation." The China Quarterly 129: 443-66.

Rao, Govinda M., Richard M. Bird, and Jennie I. Litvack. 2001. "The Changing Requirements of Fiscal Relations: Fiscal Decentralization in a Unified State." In Market Reform in Vietnam, ed. Jennie I. Litvack and Dennis A. Rondinelli. Westport: Quorum Books, 153-79.

Riedel, James, and William S. Turley. 1999. "The Politics of Economic Transition to an Open Economy in Vietnam." OECD Development Center Technical Paper 152, Paris.

Schwarz, Adam. 1996. "Enemy No. 1.” Far Eastern Economic Review, July 11.

SGGP. 1991. "So kinh te ngoai giao thanh pho kien nghi nhieu bien phap XNH." [The Department of External of Economic Relations of HCMC decides on several procedures to reduce the costs of import-export procedures]. Sai Gon Giai Phong [Liberation Saigon], April 29.

SGGP. 1993a. "Thanh tra nha nuoc kien nghi CP cho phep tinh Ba Ria Vung Tau chinh thuc duoc su dung quy dat tao von so ha tang." [Investigation of the state into the government's decision to allow BRVT use land use rights as collateral for infrastructure construction]. Sai Gon Giai Phong, December 6.

SGGP. 1993b. "Quy trinh va nguoc quy trinh." [Processes and reverse processes]. Sai Gon Giai Phong, May 6.

Sheng, Yumin. 2007. "Governing Economic Openness: Provincial Level Evidence from China (1972-2002)." Comparative Political Studies 40 (4): 405-34.

Shirk, Susan L. 1993. The Political Logic of Economic Reform in China. Los Angeles and Berkeley: University of California Press.

Shirk, Susan L. 1994. How China Opened Its Door: the Political Success of the PRC's ForeignTrade and Investment Reform. Washington: The Brookings Institution.

Simmons, Beth A., and Zachary Elkins. 2004. "The Globalization of Liberalization: Policy Diffusion in the International Political ?A3B2 tlsb?> Economy." American Political Science Review 98 (1): 171-89.

Snyder, Richard. 2001. "Scaling Down: The Subnational Comparative Method." Studies in Comparative International Development 36 (1): 93-110.

Solnick, Steven 1998. "Will Russia Survive? Center and Periphery in the Russian Federation." In Post-Soviet Political Order: Conflict and State Building, ed. Barnett R. Rubin and Jack Snyder. London and New York: Routledge, 58-80.

Taipei Times (On-Line Edition). 2006. "Intel Chooses Vietnam for New Factory." March 1, 10.

Taube, Markus, and Mehmet Ogutucu. 2002. "Main Issues on Foreign Investment in China's Regional Development: Prospects and Policy Challenges." Foreign Direct Investment in China: Challenges and Prospects for Regional Development. Paris: Organization for Economic Cooperation and Development.

Thayer, Carlyle. 2002. "Pragmatic Leader Keeps Reform within Limits." South China Morning Post, December 10.

Tonneson, Stein. 2000. "The Layered State of Vietnam." In State Capacity in East Asia, ed. Kjeld Erik Brodsgaars and Susan Young. New York: Oxford University Press, 23668.

Treisman, Daniel. 1999. "Political Decentralization and Economic Reform: A Game-Theoretic Analysis." American Journal of Political Science 43 (2): 488-517.

$\mathrm{Tu}, \mathrm{Vu}$ Huy. 1987. "Some Thoughts on Guaranteeing the Production and Business Independence of Basic Economic Units." Tap Chi Cong San, August.

Turley, William, and Brantly Womack. 1998. "Asian Socialism's Open Doors: Guangzhou and Ho Chi Minh City" The China Journal 40 (July): 95-120.

UNCTAD. 1990-2001. United Nations Conference on Trade and Development. http://www.unctad.org/Templates/Page.asp?intItemID=1923\&lang $=1$ (August 25, 2007).

Van Arkadie, Brian, and Ray Mallon. 2003. Viet Nam: A Transition Tiger? Canberra, Australia: Asia Pacific Press.

Vietnamnet, 2006A. "PM empowered to suspend provincial chairperson." September 7. www.veitnamnet.com.vn (December 8, 2007).

Vietnamnet 2006B. "Corruption Committee Can Suspend Ministers." May 30. www.veitnamnet.com.vn (December 8, 2007).

Vaskavakul, Thaveeporn. 1997. "Sectoral Politics for State and Party Building." In Doi Moi: Ten Years After the 1986 Party Congress, ed. Adam Fforde. Canberra: Australia National University, 80-136.

Vaskavakul, Thaveeporn. 2002. Rebuilding Authority Relations: Public Administration Reform in the Era of Doi Moi. Hanoi: Asian Development Bank

Vaskavakul, Thaveeporn. 2003. "From Fence-Breaking to Networking: Interests, Popular Organizations, and Policy Influences in Post-Socialist in Vietnam." In Governance in Vietnam: The Role of Organizations, ed. Russel Heng, Benedict J. Kerkvliet, and David Koh. Singapore: Institute of Southeast Asian Studies, 25-61.

Vinh Phuc Statistical Office. 2001. Statistical Handbook. Vinh Phuc, Vietnam.

Vietnam Competitiveness Initiative and Vietnam Chamber of Commerce and Industry (VNCI). 2005. "Summary Report on the Provincial Competitiveness Index on the Business Environment in Vietnam." US-AID: Hanoi, Vietnam. Data available at www.vnci.org (August 24, 2007).

VIR. 1996. "Provinces Push for New powers." Vietnam Investment Review, November 11.

VIR. 1997. "Greater Autonomy for Provinces." Vietnam Investment Review, March 3. Vuving, Alexander. 2006. "Strategy and Evolution of Vietnam's China Policy: Changing Mixture of Pathways." Asian Survey 46 (6): 805-24.

Wang, Shaoguang. 1995. "The Rise of the Regions: Fiscal Reform and the Decline of Central State Capacity in China." In The 
Waning of the Communist State: Economic Origins of Political Decline in China and Hungary, ed. Andew Walder. Berkeley: University of California Press, 87-114.

Whiting, Susan H. 2001. Power and Wealth in Rural China: The Political Economy of Institutional Change. New York: Cambridge University Press.

World Bank. 1996. Vietnam: Fiscal Decentralization and the Delivery of Rural Services. Hanoi: World Bank.

World Bank. 2002. Vietnam's Equitized Enterprises: An Ex-Post Study of Performance, Problems and Implications for Policy. Hanoi: World Bank.

World Bank. 2004. World Development Indicators. Washington, DC: World Bank, http://publications.worldbank.org/ecommerce/catalog/product-detail?product_id=6355220\&.
Yui, Yuji. 2006. "FDI and Corporate Tax Reform in Vietnam." Unpublished Manuscript. University of Tokyo.

Ziblatt, Daniel. 2004. "Rethinking the Origins of Federalism: Puzzle, Theory, Evidence from Nineteenth-Century Europe." World Politics 57 (October): 70-98.

Zweig, David. 2002. Internationalizing China. Ithaca: Cornell University Press.

Edmund J. Malesky is assistant professor of international relations and Pacific studies, Harvard University, Cambridge, MA 02138. 